\title{
السياسة القانونية لحماية سلامة الغذاء في الملككة العربية العماية السعودية
}

\author{
دكثور \\ مسفر بن حسن مسفر القحطاخي \\ استاذ الانظمة الشارك بقسم العلوم القانونية \\ كلية الملك فهد الامنية الرياض الملكة العربية السعودية
}


العدد الأول- الجزء الثاني- السنة الثامنة والخمسوذ-يناير rا.r

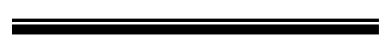

السياسة القانونية لحماية سلامة الفذاء في المملكة العربية السعودية ع 


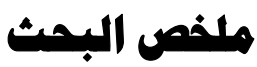

يهدف البحث الى تحقيقا لأهداف التالية:

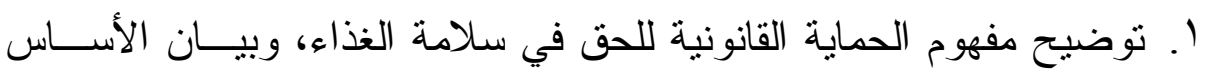

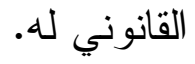

r. توضيح أدو ار الهيئة العامة للغذاء و الدواء في حماية سلامة الغذاء. r. بيان استز اتيجية نظام الغذاء في المملكة في تحقيق سلامة الغذاء وجودته.

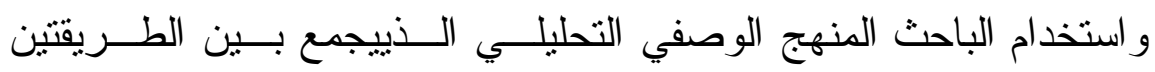

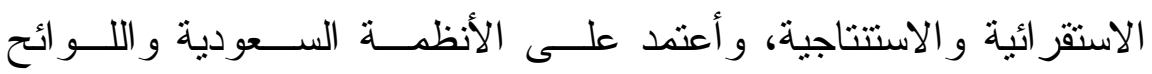
التفسيرية.

وتوصل الباحث إلى مجموعة من النتائج و التوصيات يعرض لأهمها: أو لاًا: النتائجج:

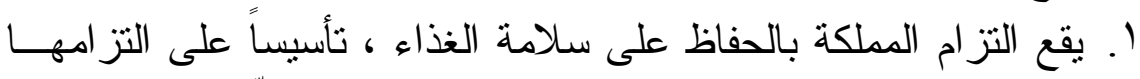

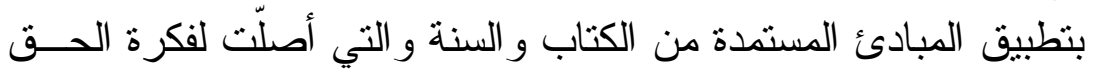
في سلامة الغذاء.

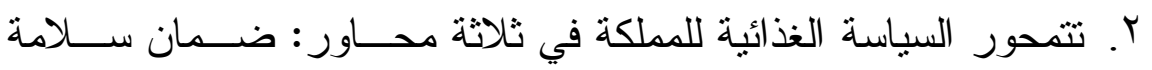

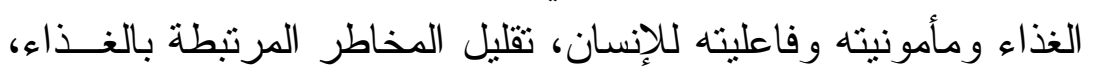

$$
\text { حماية الإنسان من الغذاء الضار أو المغشوش. }
$$

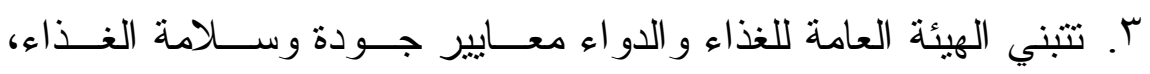
و استخدام احدث الطرق و الاساليب العلمية الحديثة في ضبطها.

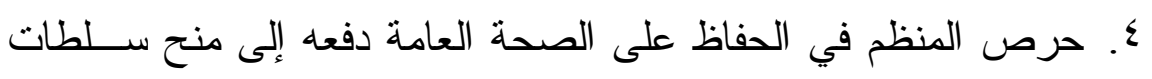

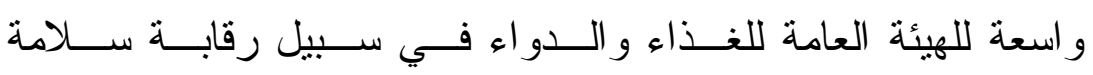

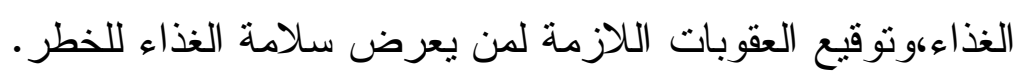
ثانياً: التوصيات: ا. الاهتمام و المر اجعة الدورية للشــروط الصــــية و المو اصــفات القياســية

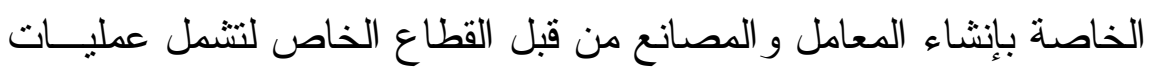
التصنيع و التخزين و التجهيز و التوزيع للأغذية.

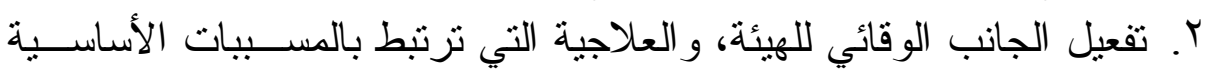

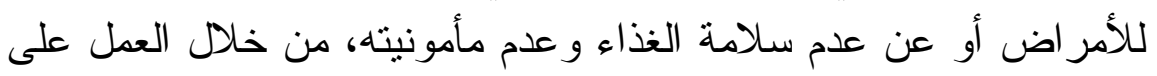
خلق بيئة نظيفة وصحية. 


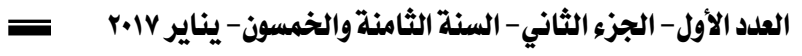

r. إنثاء لجنة قانونية مستقلة لمساعدة مجلس الإدارة، وتقديم المشورة لها في

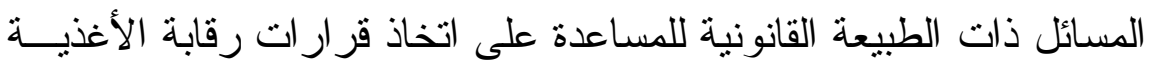

$$
\text { وسلامتها. }
$$

ع. ضرورة إنشاء مختبر ات وهيئات مستقلة عن الهيئة العامة للغذاء و الــدو اء

تقوم بالتحليل و أخذ العينات. 


\section{Research summary}

The research aims to obtain this objectives :

1. Clarify the concept of legal protection to the right of food safety right and state the legal basis to it.

2. Clarify the role of SFDA in food protection.

3. State the strategy of food law in the kingdom in accomplishing food safety and quality.

Researcher using descriptive and analytical approach that combines inductive and deductive methods, and rely on Saudi laws and regulations explanatory.

The researcher obtained a set of findings and recommendations shall be subjected to the most important: First: results:

Kingdom's commitment to maintaining the safety of food, built on its commitment to implement the principles derived from the Quran and Sunnah, which has structured the idea of the right to food safety.

Food policy of the Kingdom focus on three areas: ensuring the safety of food and its safety and effectiveness of the human being, reduce the risks associated with food, human protection from harmful or adulterated food. The General Authority for Food and Drug Administration adopt standards of quality and safety of food, and the use of latest methods and modern scientific methods tuned in. The law maker had make sure of maintaining public health led him to grant wide powers of the General Authority for 
Food and Drug Administration for food safety control and punish who may jeopardize food safety.

Second: Recommendations:

1. Attention and periodic review of health conditions and standards for the establishment of laboratories and factories by the private sector to include manufacturing, storage, processing and distribution of food operations.

2. Activate the preventive aspect of the SFDA, and treatment that are related to the basic causes of disease or lack of food safety and danger, by working to create a clean and healthy environment.

3. Establishment of an independent legal committee to assist the Board of Directors, and to advise them on matters of a legal nature to help take control and food safety decisions.

4. The importance of establish an independent laboratories and bodies for the General Authority for Food and Drug Administration based analysis and sampling. 


\section{مقدمة مقة}

إن الحمد لله نحمده ونستعينه ونستخفره ونعوذ بالله من شرور أنفسنا

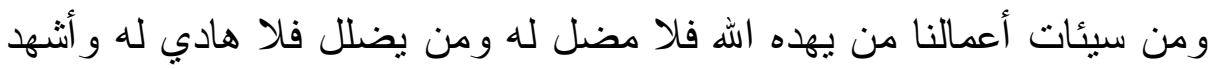

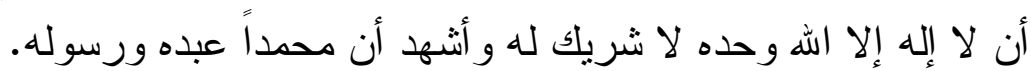
أما بعد:

يعتبر الغذاء مصدر الحياة وشريانها على سطح الأرض فقد أدرك الإنسان منذ زمن بعيد دور و أهمية الغذاء كمصدر للطاقة و النشاط و الحيوية الأية ووقايته وحمايته من الأمر اض إلا أن ذلك الغذاء الغذاء أصبح سلاحاً ذو حدين

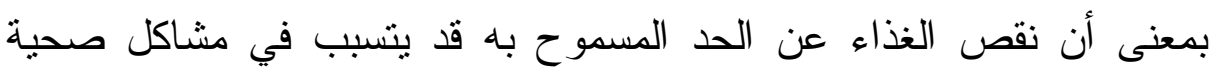
كبيرة، وتناول غذاء غير سليم يمثل مشكلة أكبر .

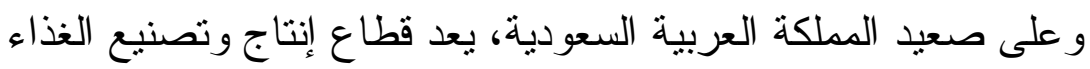
من القطاعات المهمة، فهناك العديد من المصانع المنتجة للغذاء و التي يقدر عددها بأكثر من ثلاثمائة مصنع بالإضافة لوجود عدد من مؤسسات الخدمات

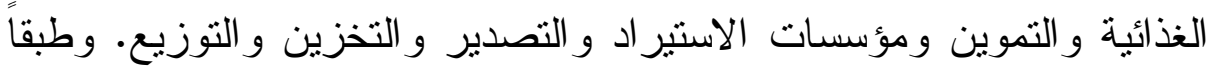

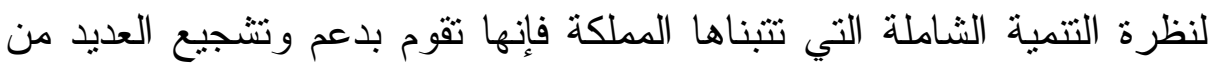
المشروعات الصناعية في شكل منح القروض و المشاركة في رأس المال

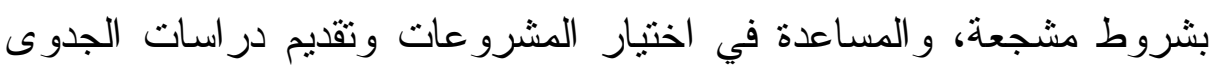

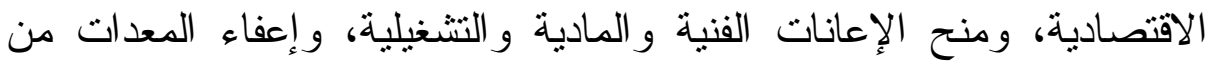

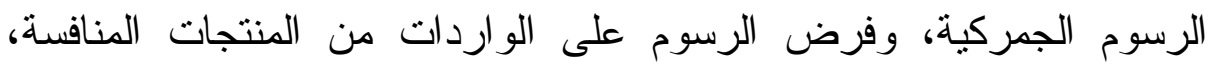

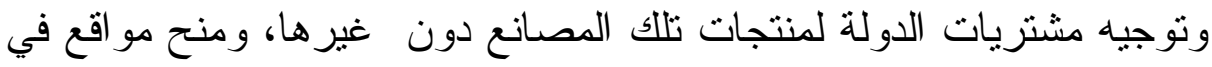

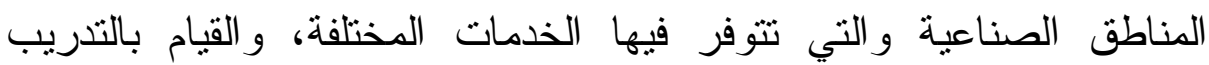
للسعوديين وتشجيع الصناعات في مجال الغذاء ومساعدة المنتجين في ذلك (').

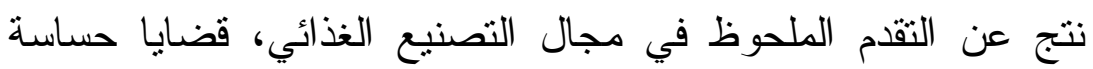
شغلت انتباه الجميع وخاصة مستهلك السلع الغذائية، وهي قضية سلامة فئه الغذاء

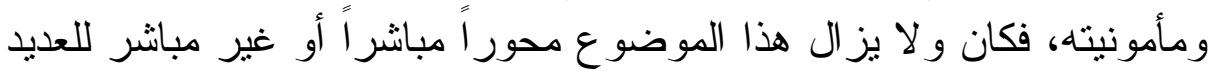

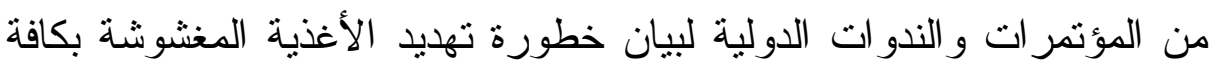

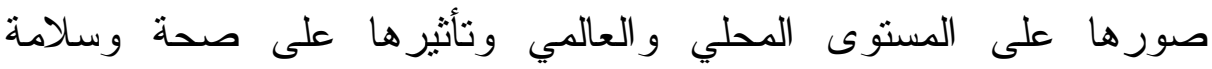

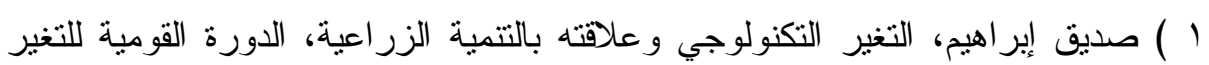

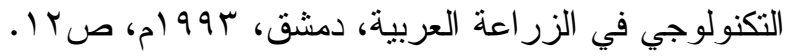


المستهلك، وتحليل وضع الأغذية في المملكة، وتحديد دور الجهات المعنية في مكافحة الأغذية الغير آمنة ومنعها من الوصول إلى المستهلك، كل ذلك دفع

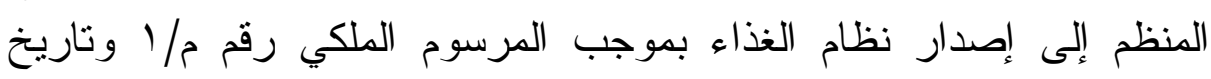

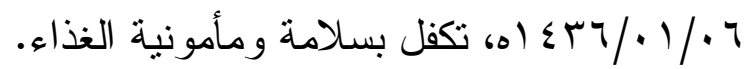

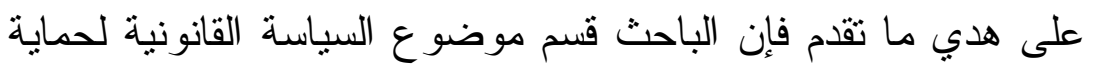

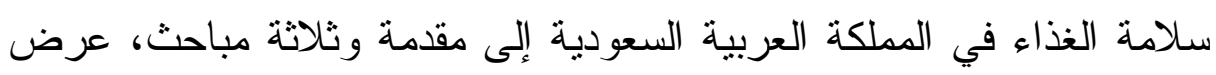

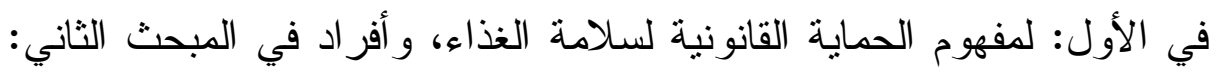
دور الهيئة العامة للغذاء و الدو اء في حماية سلامة الغذاء، وتحدث في المبحث الثالث: استر اتيجية المملكة في تحقيق سلامة الغذاء وجودته.

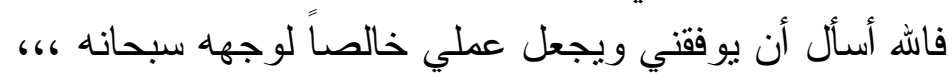


العلد الأول- الجزء الثاني- السنة الثامنة والخمسون- يناير |r.

\section{المبمث الأول}

\section{مفهوم الهماية القانونية لسلامهة الغذاك}

سوف نتناول في هذا المبحث مفهوم الحماية القانونية لسلامة الغذاء

من خلال عرضه في ثناث مطالب على النحو الآتي:

المطلب الأول: المقصود بالحق في سلامة الغذاء

المطلب الثاني: الأساس القانوني للحق في سلامة الغذاء

المطلب الثالث: ضو ابط حماية غذاء الإنسان الانسان

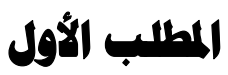

\section{الاقمصود بالمق في السامة الغذاء}

يكتسب مفهوم الحق في سلامة الغذاء أهمية كبيرة في المو اثيق الدولية

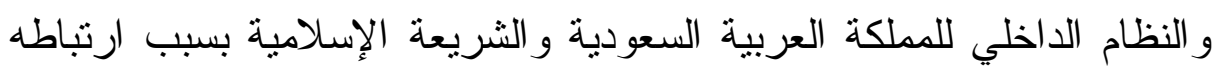
بحق الإنسان في الحياة. أولاً: مفهوم الحق في سلامة الإنسان فئاء الغذاء دولياً:

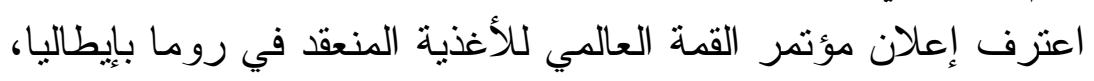

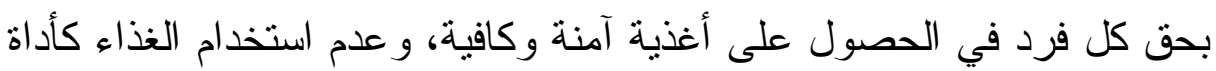

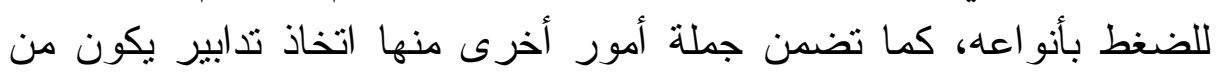

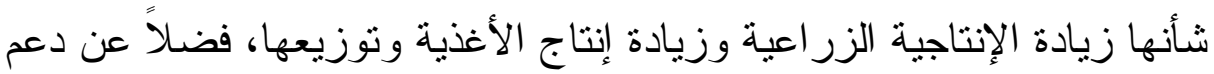

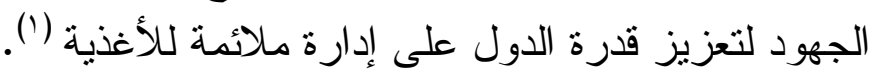

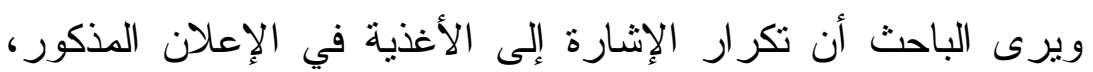

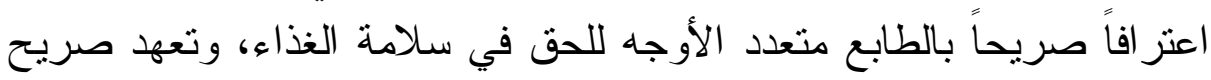

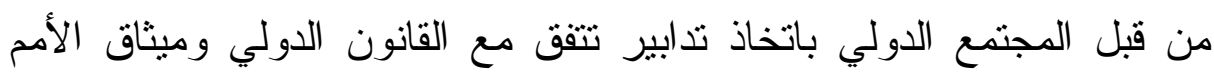

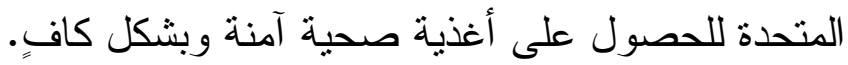

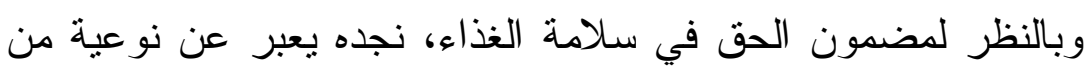

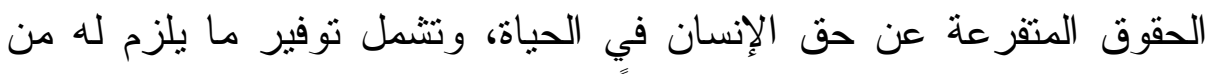

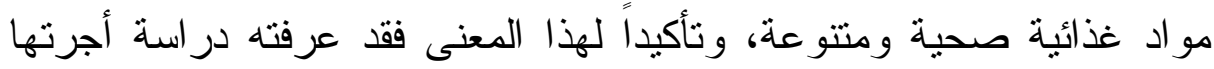
منظمة الأغذية و الزر اعة التابعة للأمم المتحدة بأنه: "لكل رجل ولهية وامر أة وطفل

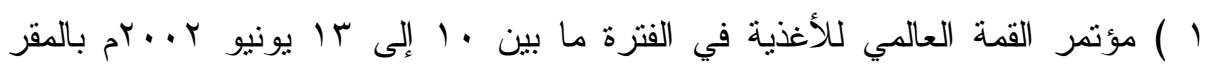

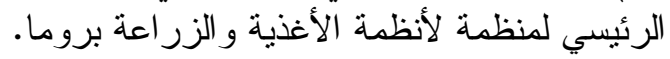


بمفرده أو مجتمعاً مع آخرين الحق في الحصول بصورة مادية و اقتصادية،

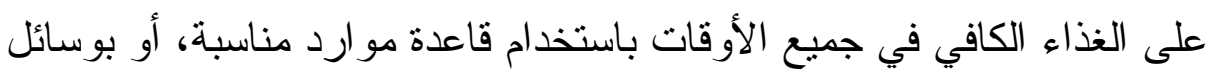

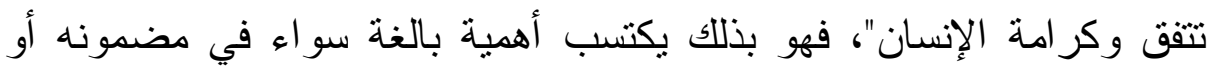
أبعاده لعلاقته بالإنسان وكر امته وحياته (').

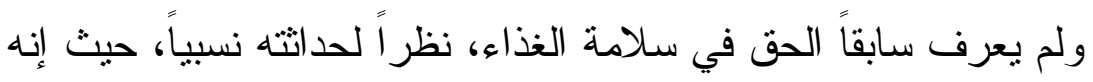

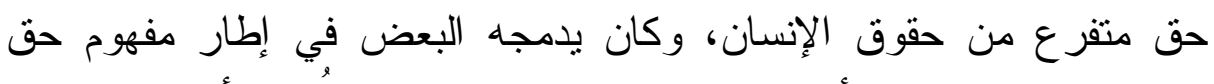

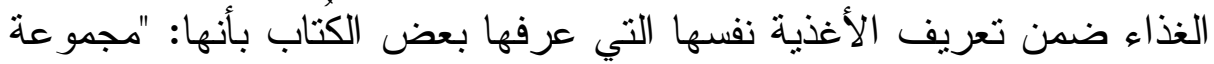

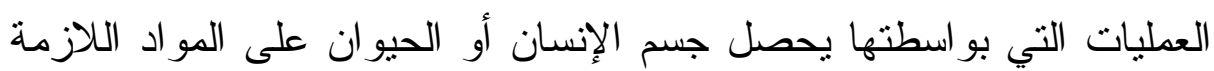

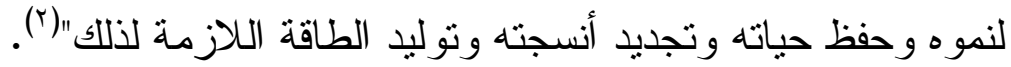

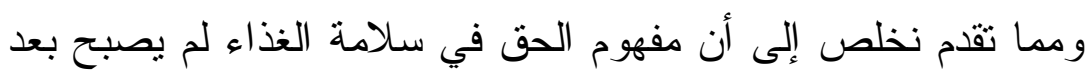

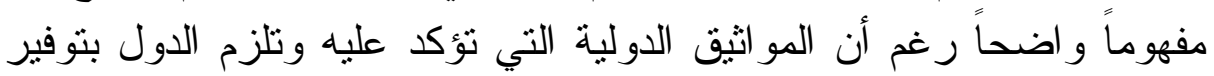

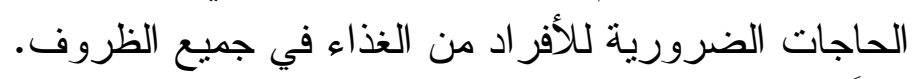
ثانياً: مفهوم الحق في سلامة الغذاء في الثريعة الإسلامية:

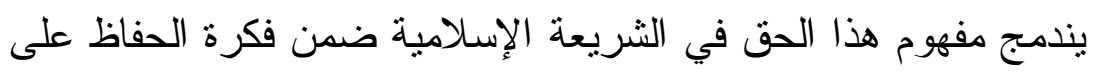

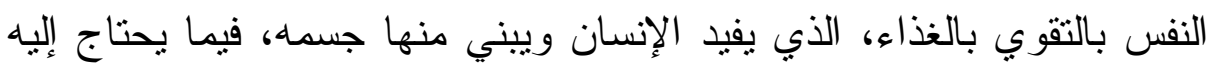

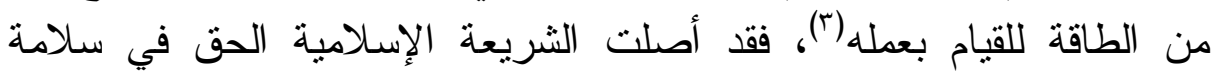

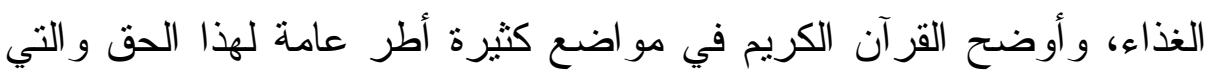

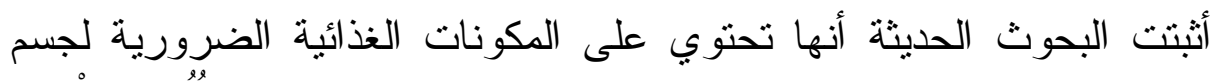

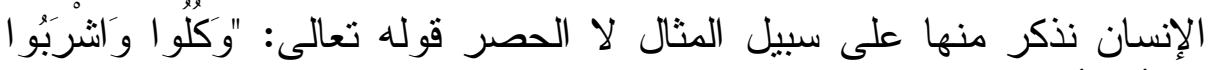

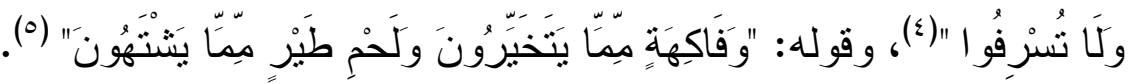

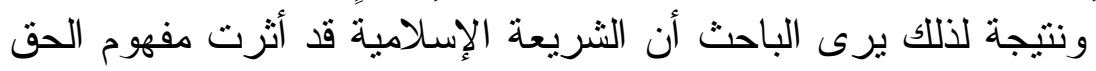

$$
\text { في سلامة الغذاء من نواحي عدة نوجز ها في الآتي: }
$$

( ) دراسة منظمة الأغذية و الزراعة للأمم المتحدة: بعنو ان الحق في الغذاء بين النظرية

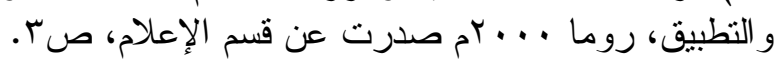
r ) رجاء الطنوس، الغذاء و التغذية المنوازنة، معهد الإنماء العربي، بيروت، ، •91 ام،

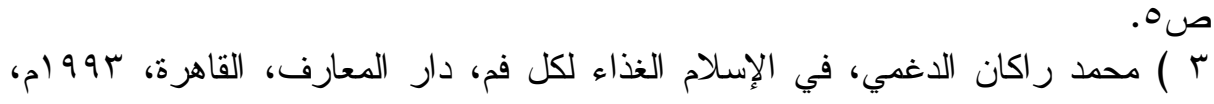
صVا. ع ) سورة الأعر اف الآية الب.

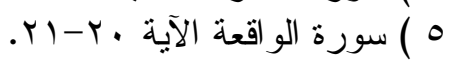


1. مساهمتها في إعطاء مفهوم موسع يشمل كل ما يتغذى بـ الإنسان من

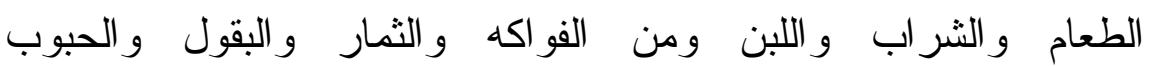

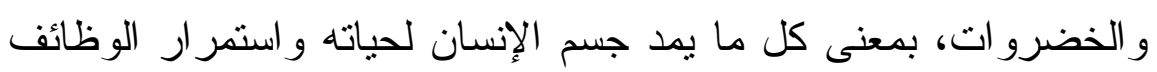

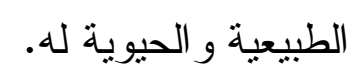

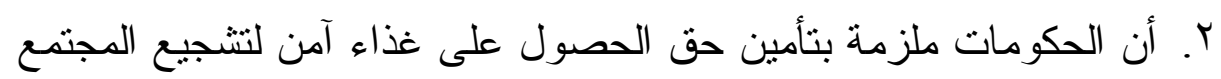

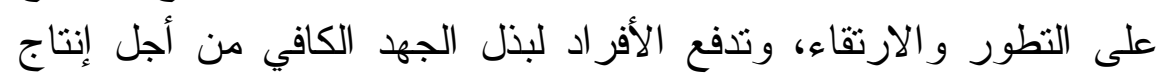

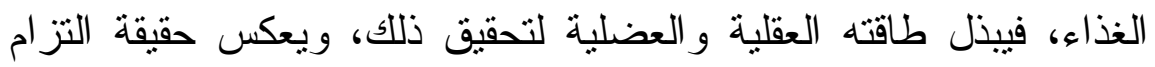

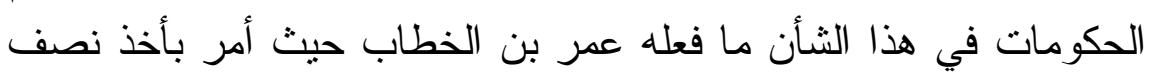

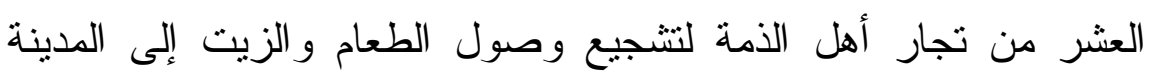
المنورة، وكذلك فعل عمر بن عبد العزيز (').

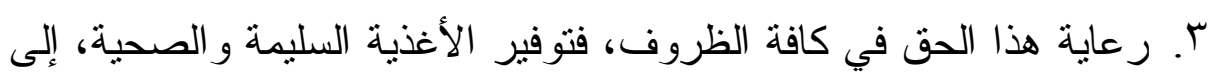

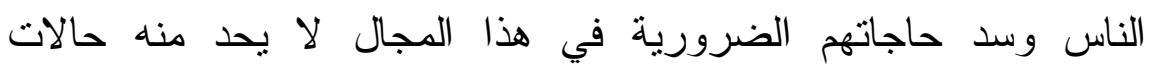
الاضطر ابات و التوتز ات الداخلية ولا حالات الطو فئ فئ.

ع. ينسحب مفهوم الحق في الغذاء إلى الحق في سلامته وكفايته اللازمنين للإنسان، بشكل لا يقبل الانفصام أو التجزئة.

○. وضع ضو ابط و اضحة للغذاء منها التوازن في تتاوله بشكل كافي وغير زائد عن حاجة الجسم، بالإضافة الى ضرورة أن يكون سليم وصحي.

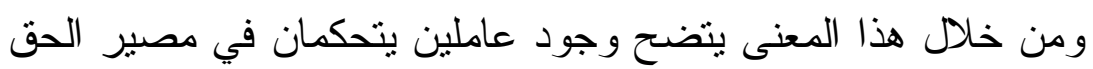
في سلامة الغذاء، أولهما: التزام الدولة بتوفير الغذاء الصدي ودي والمناسب

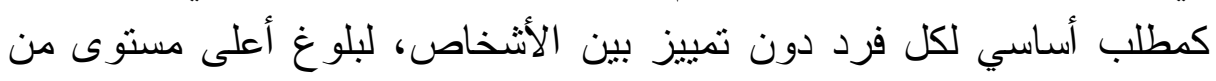

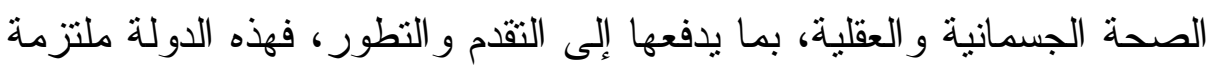

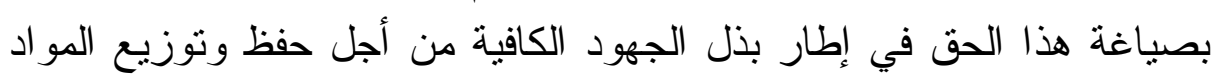
الغذائية و الاستفادة الكلية من المعارف التقنية العلمية في هذا المجال، وبنشر

( ) عبد العزيز محمود عبد العزيز، مشكلة الغذاء في العالم الإسلامي، الهيئة المصرية

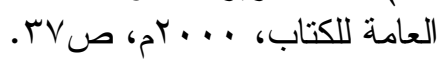


المعرفة بثقافة ومبادئ التغذية و إصلاح نظم توزيع الأر اضي الزر اعية بطريقة تكفل أفضل إنماء للمو ارد الطبيعية.

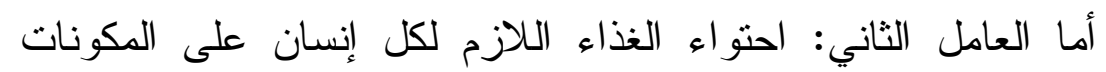

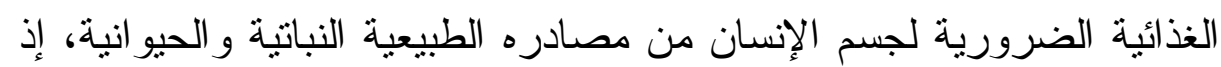

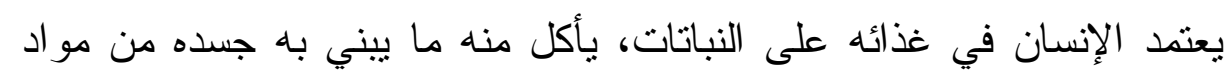

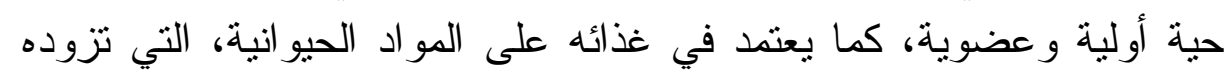
بالطاقة اللازمة لحياته وفي بناء خلاياه. ثالثاً: مفهوم الحق في سلامة الغذاء في النظام: لهاء

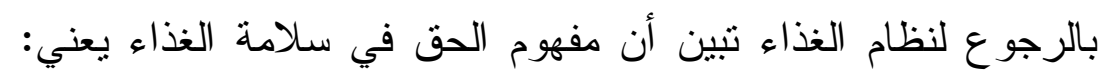

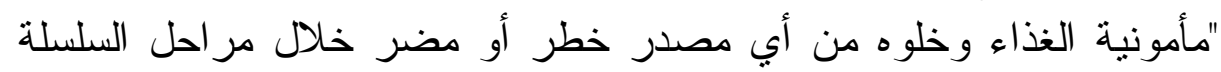

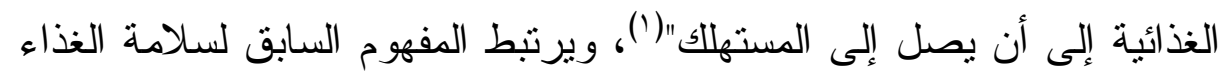

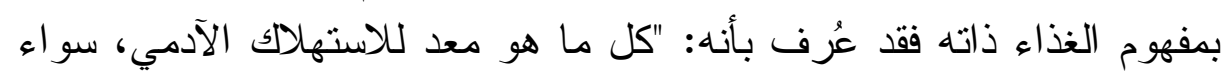

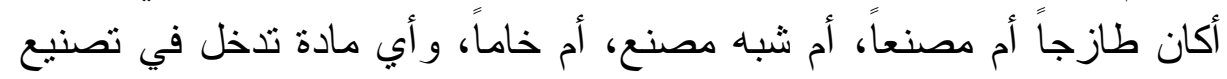
الغذاء أو تحضيره أو معالجنه" (؟). ويرى البعض أن جودة وسلامة الغذاء مفهومان متلازمان ومرتبطان

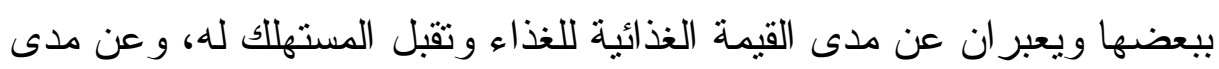
صلاحية الغذاء للاستهلاك وخلوه من كل ما يضر بصحة ملفئ المستهلك. و الجودة الغذائية تعنى احتفاظ الغذاء بجميع أو معظم صفاته وخو اصده الحسية و الطبيعية و الكيميائية و الغذائية، في حين تعني سلامة الغذاء خلوه من جميع مصادر

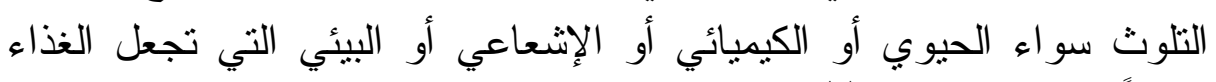
ضار اً بصحة المستهلك (َ). وللجهات المعنية في سبيل الحفاظ على سلامة الغذاء خلال المراحل التي يمر بها، اتخاذ كافة التدابير الصحية لسلامته و التي من شأنها حماية حياة

( ) الفقرة 1 من المادة الأولى من نظام الغذاء الصادر بموجب المرسوم الملكي رقم م/1 إه

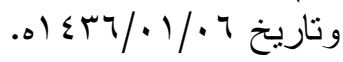

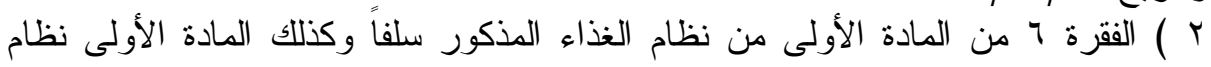

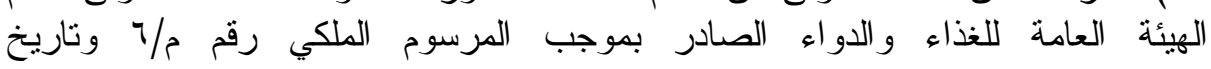

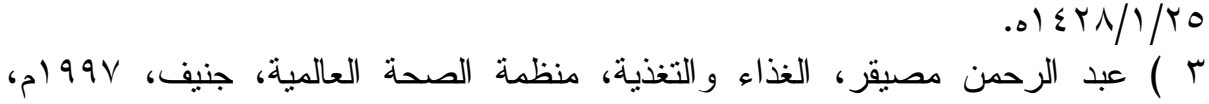
صזr. 
الإنسان وصحته من المخاطر الناتجة من المضافات الغذائية و الملوثات

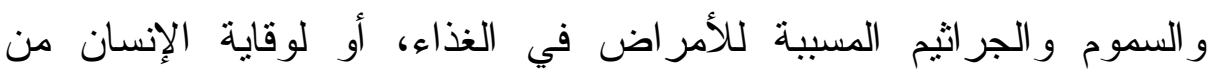

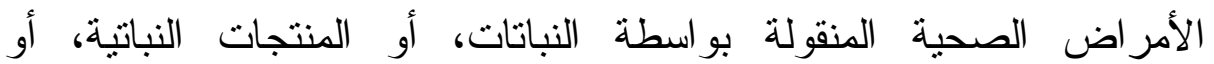

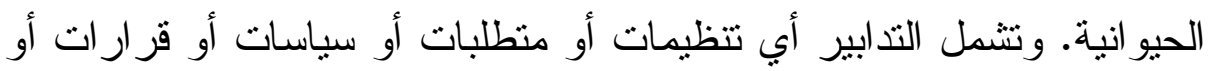
إجر اءات ذات علاقة مباشرة بسلامة الغذاء (').

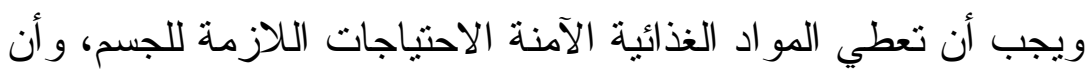
توفر جميع العناصر الأساسية له، بما في ذلك الفيتامينات و البروتينات، فضلاتلاً الإنة

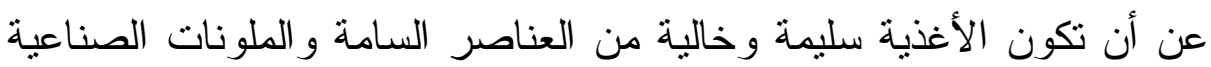
وينبغي أن يكون الغذاء ذو نوعية جيدة من حيث المذاق و القو ام) (r).

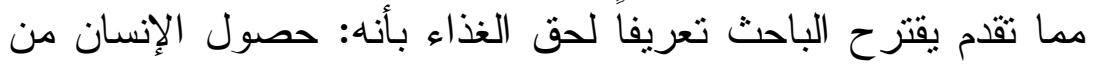

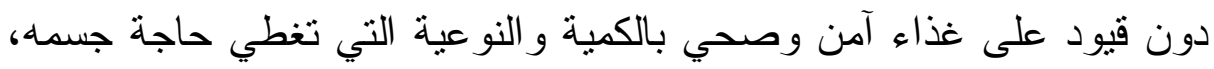

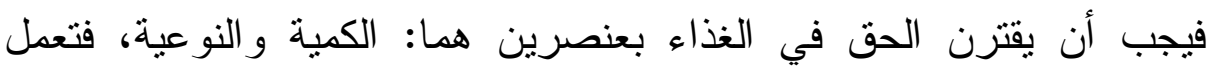
الأولى على سد حاجة الجسم للغذاء، بينما تعمل الثانية على اتزان صنئ صحته

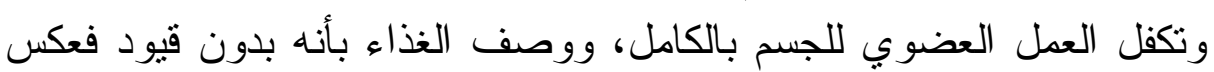

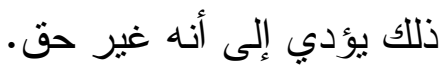

\section{الاطبا الثاني}

\section{الأساس القانوني لامق في سلامهة الغذاء}

إن وجود الحق في سلامة الغذاء كحق متفرع من حقوق الإنسان،

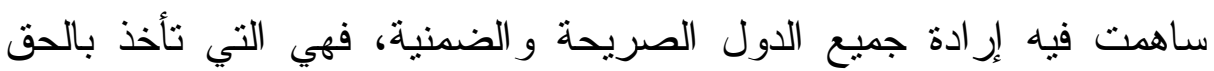
الأساسي لكل فرد أو تعترض عليه، ورلا يمكن أن يقوم ذلك الحق إلا على إلى إلى

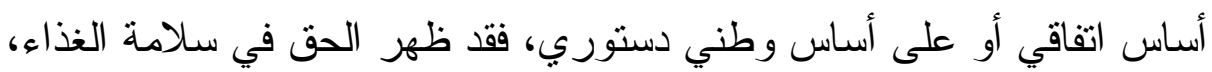

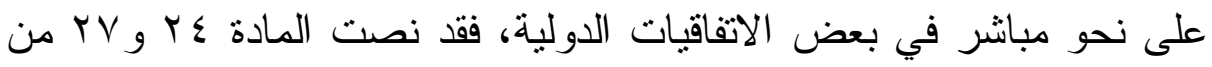

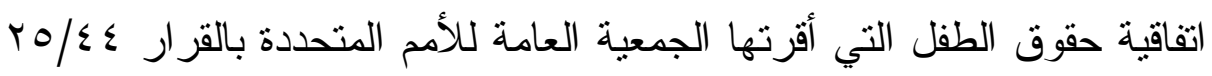

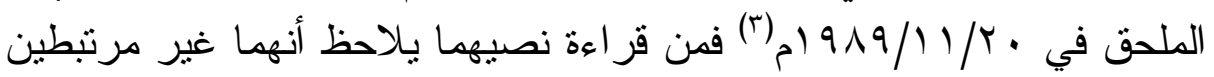

( ) الفقرة ع ب من المادة الأولى من نظام الغذاء المشار إليه.

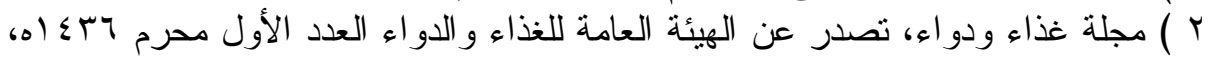

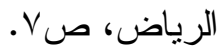

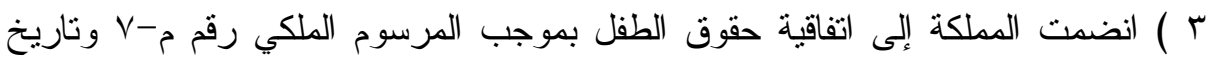

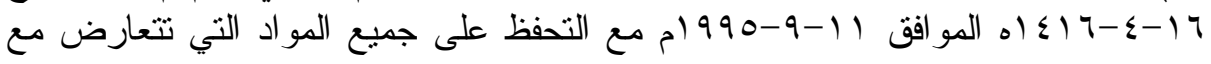


مباشرة بالغذاء بل يعبران على نحو أو آخر عن الحق في سلامة الغذاء و أبعاده الذي وجد له اعتر افاً في القانون الدولي.

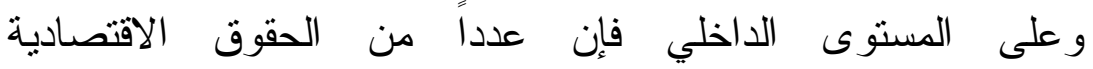
و الاجتماعية، ومنها الحق في سلامة الغذاء، قد صيغت في إطار النظام القانوني للمملكة العربية السعودية صياغة تبدو دقيقة ومفصلة بقدر كافٍٍ، و هذا يفرض على الباحث التطرق لأمرين الأول: النص على حماية سلامة دئة الغذاء

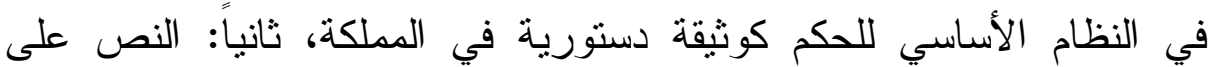
حماية سلامة الغذاء في الأنظمة العادية في المملكة، على النحو الآتئي أولاً: حماية الغذاء في النظام الأساسي للحكم:

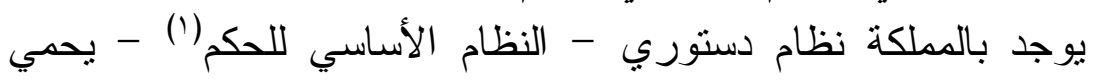
حقوق الإنسان، وما ينبثق عنه من حقوق وحريات من جهة، ووجود ضمانات

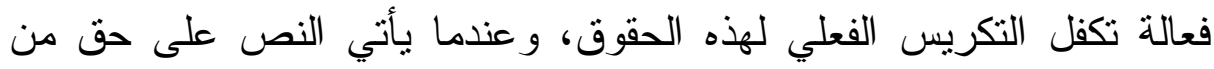
الحقوق بالنظام الأساسي للحكم يعتبر ذلك رأس هذه الضمانات و أهمها، لما لها تتمتع به نصوص النظام الأساسي للحكم من سمو ورفعة على ما عداه منٍ نصوص نظامية عادية تدنوه درجة في الهــرم القـانوني للمملكة، إعمالاً

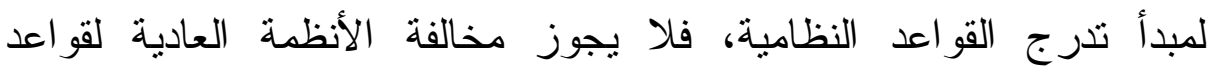

ونصوص النظام الأساسي (؟). فقد حرص المنظم على تضمين النظام الأساسي للحكم أكثر الموضوعات المرتبطة بالحقوق والحريات، وكلما اهتم المنظم الدستوري

الثريعة الإسلامية، ونم إيداع وثثقة انضمام المملكة للاتفاقية المذكورة لدى الأمين العام

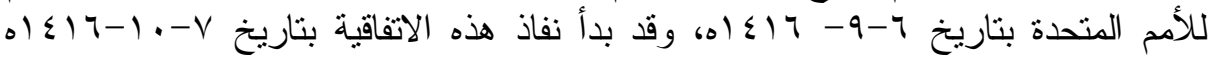

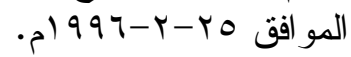

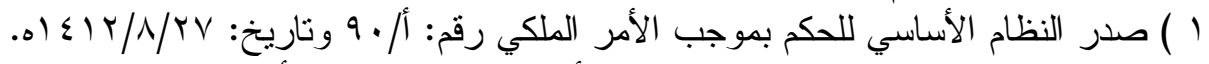

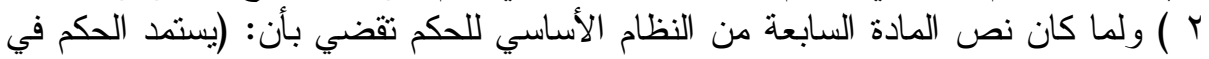

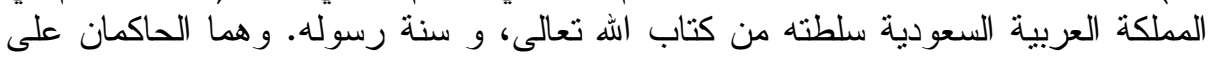

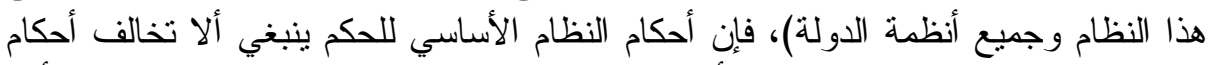

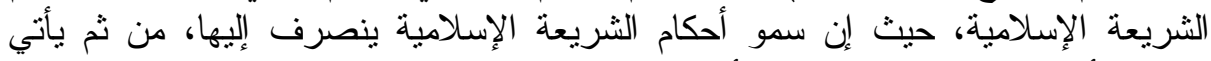
النظام الأساسي للحكم في الارجة الأقل مباشرة منها. 
بموضوعات معينة نص عليها بشكل مباشر أو غير مباشر في النظام الأساسي للحكم، لكي يضفي عليها مكانة سامية في هذا النظام ('). ومن هذه الأمور المنظمة أمن وسلامة المجتمع وحياة أفر اده، ويعتبر

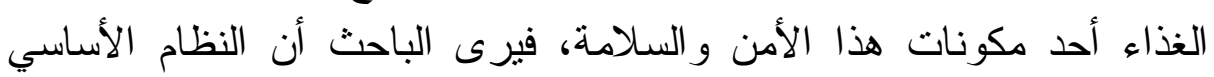

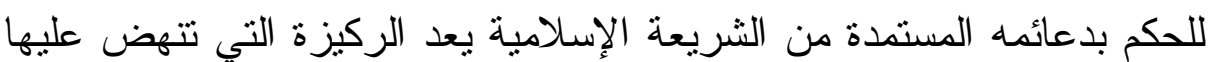
قو اعد الأنظمة الأخرى، وتجد فيه مصدر ها ومشرو عيتها.

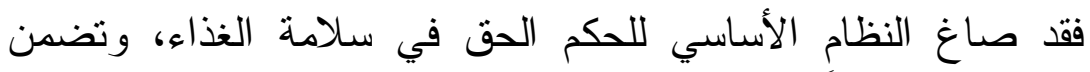

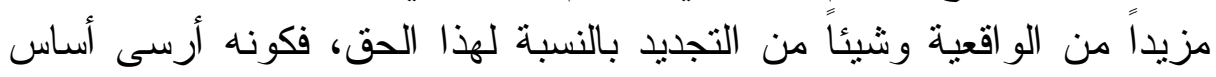
الالنز ام القانوني بالحق في سلامة الغذاء، بوضعه كقاعدة أساسية في النظام

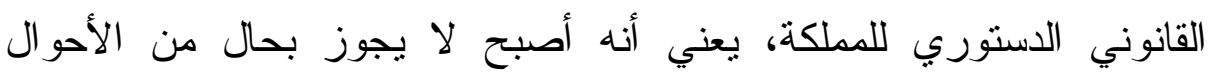

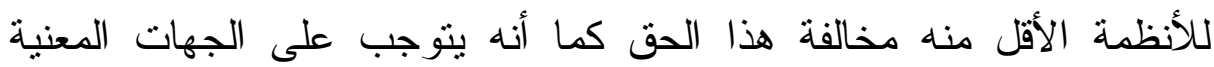

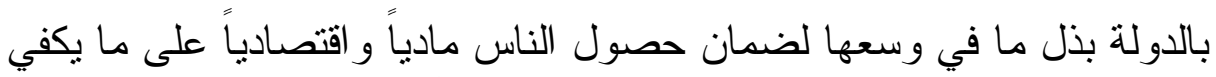

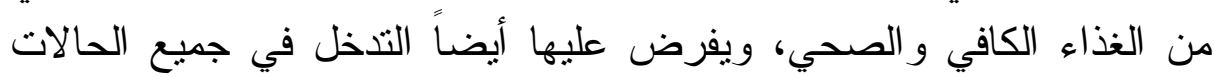
ووضعها قو اعد ملزمة لتنظيم السلوك الاجتماعي وفقاً للضرورات ولفئ الغذائية.

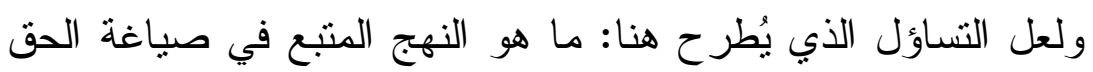

$$
\text { في سلامة الغذاء بالمملكة ؟ النماول }
$$

انتهجت المملكة في صياغة هذا الحق ما تضمنه النظام الأساسي للحكم حيث تنين أن المادة السابعة منه تضمنت التالي: (يستمد الحكم في المملكة العربية السعودية سلطته من كتاب الله تعالى، وسنة رسوله. وهما الحاكمان

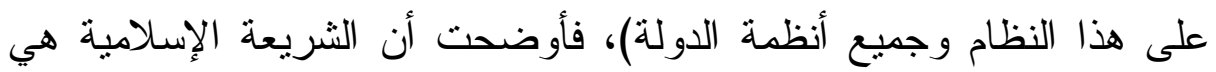

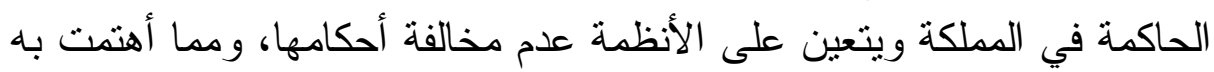
الثريعة الإسلامية حفظ النفس كضرورة من الضروريات الخمس.

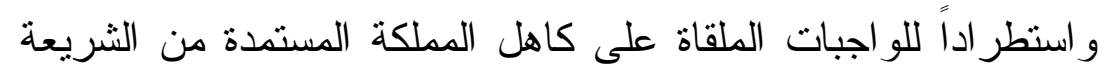

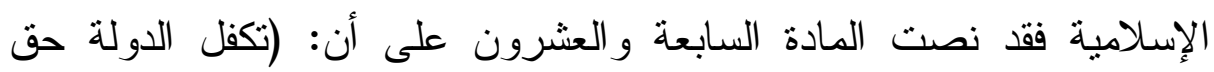

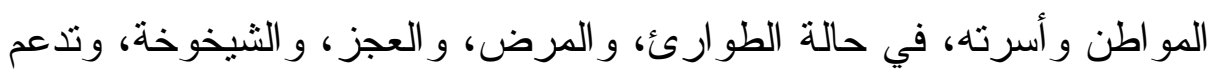

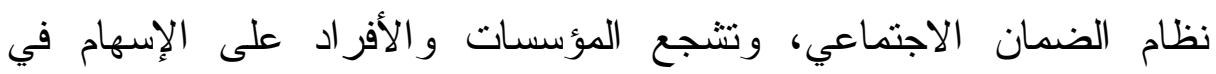
الأعمال الخيرية). (الطمان.

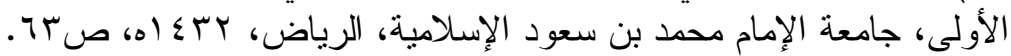




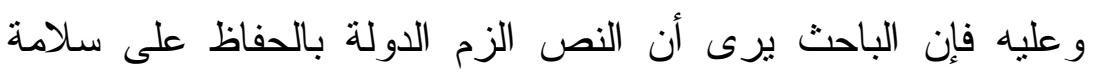

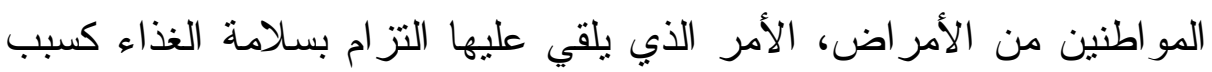

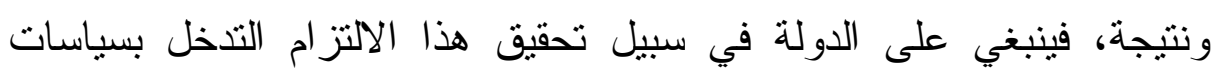
غذائية تهنم بجودة الغذاء وسلامته، وكذلك دعم الدولة لألة لنظام الضمان

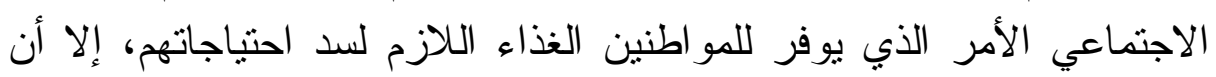
الباحث لله مأخذان على هذا النص هما: ا. كان من الأجدر النص صر احلى لهذ على كفالة الدولة للحق في سلامة الغذاء، وهي في ذلك تتبنى أصلاً إسلامياً ثابتاً.

r. النص على كفالة هذا الحق من دون تقييده وقصره على المو اطنين، لكي

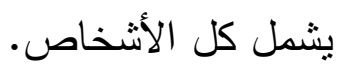

ويرى الباحث أن أساس التزام المملكة بمر اعاة وكفالة الحق في سلامة الغذاء مستمد من المبادئ العليا و التي هي مستمدة من الكتاب و السنة و الذي إني

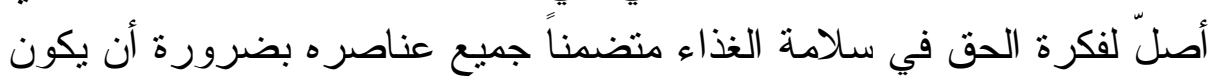

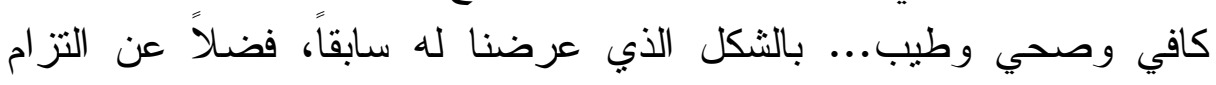
المملكة الأخلافي و الإنساني. ثانياً: حماية الحق في سلامئة الإنسانية الغذاء بالأنظمة العادية:

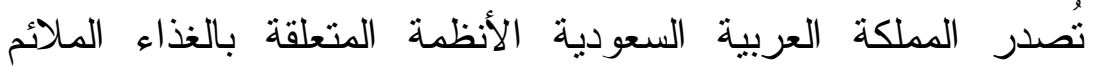

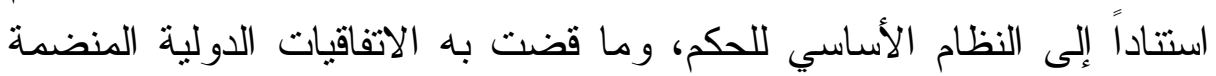

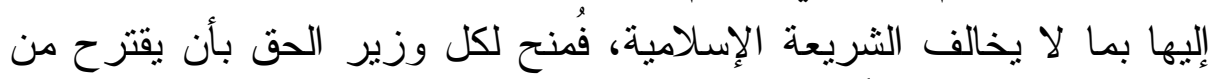

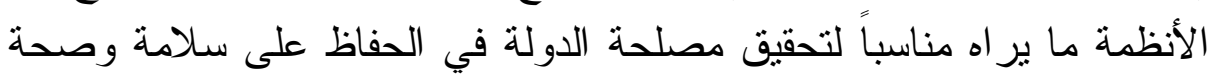
وخدمة المو اطنين، و التز اماً من الدولة بمر اعاة الحق في سلامة الغذاء ('). و عليه فإن لمجلس الوزر اء بصفته احد جناحي السلطة التنظيمية القدرة

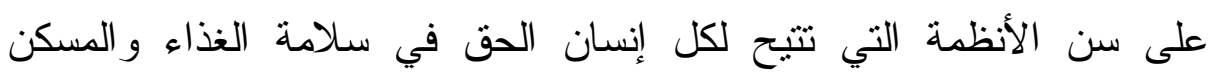

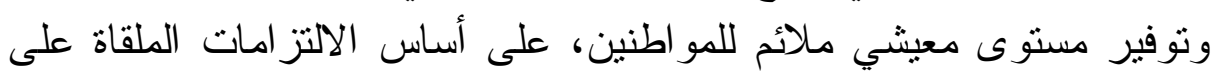

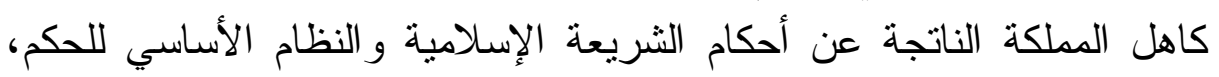

1 ) المادة r r من نظام مجلس الوزراء الصادر بموجب الأمر الملكي رقم: أ/با وتاريخ: .0) $\leqslant 1 \leqslant / \Gamma / \mu$ 
كما تقدم ذكره فإنه قد صدر نظام الغذاء بموجب المرسوم الملكي رقم م/ إ إ

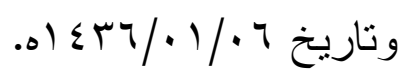

ويثور في هذا الصدد تساؤل غاية في الأهمية ألا وهو : هل يمكن

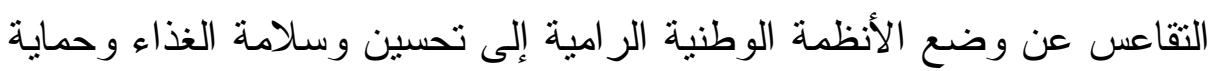

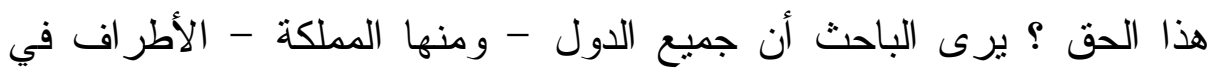
الاتفاقيات الدولية عليها واجب اتخاذ الإجر اءات اللازمة لتوفير الاحتياجات

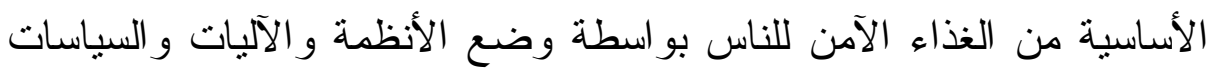

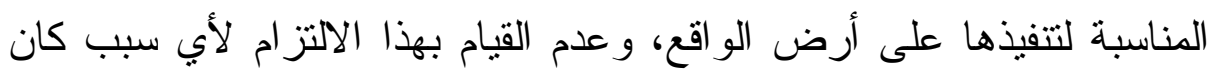

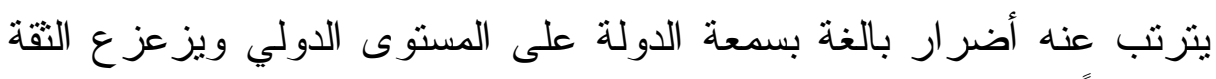

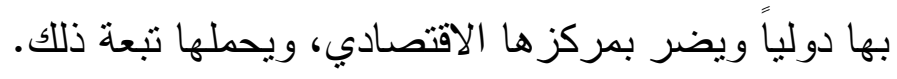

\section{الإلثب الثالث}

\section{عالاقة الأمن الغذاتي بسلامية الغذاء}

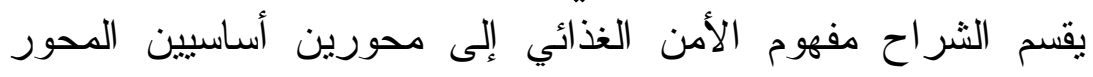

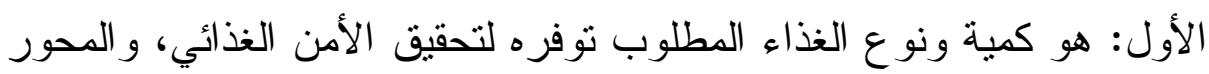
الثاني: هو كيفية الحصول على الغذاء سواء من المصادر المحلية أو الأجنبية

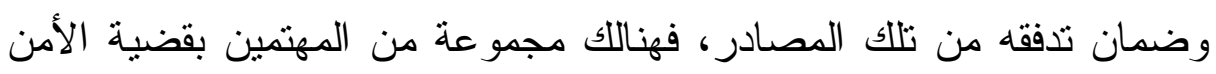

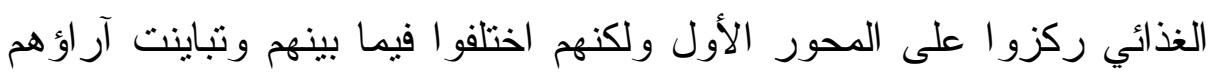
حول كمية الغذاء المطلوب نو افرها لتحقيق الأمن الغذائي. فمنهم من جعل هذه الاول

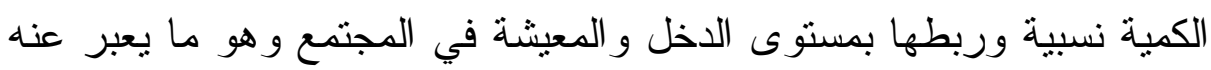

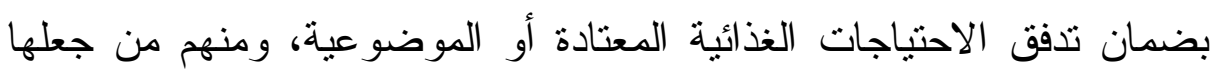

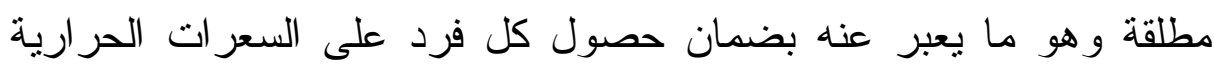

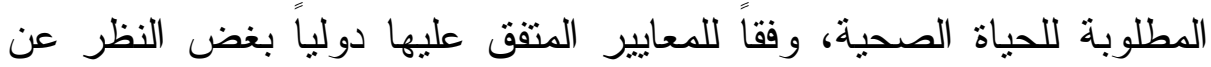
مستوى دخل الفرد و الحياة في المجتمع (')

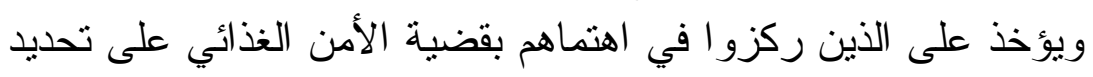

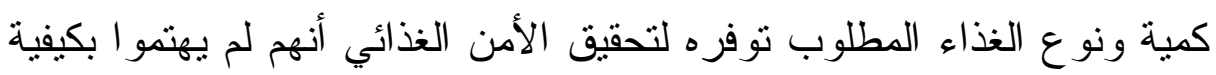

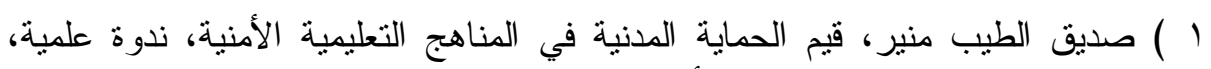

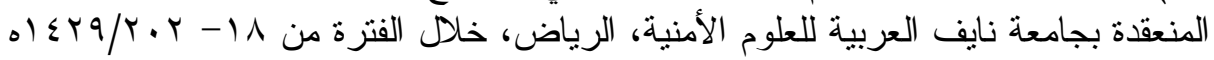

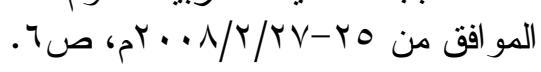


وسبل تحقيق الأمن الغذائي وبالتالي يعتبر اهتمامهم نظرياً وليس علمياً، وفي

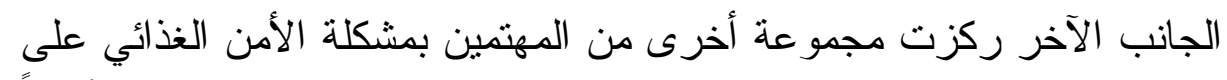

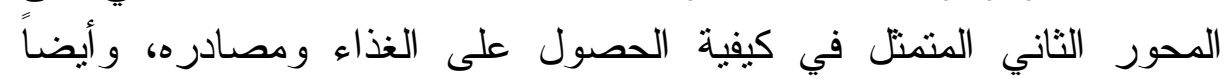
اختلف هؤلاء وتباينت وجهات نظرهم حول كيفية الحصول على كمية الغذاء التي تحقق الأمن الغذائي (').

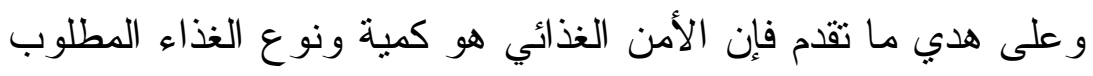

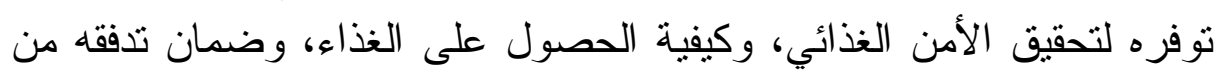

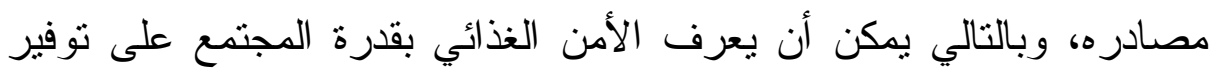

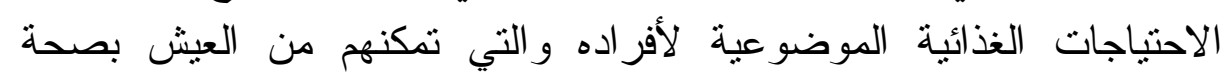

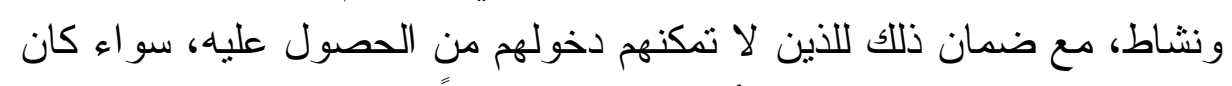

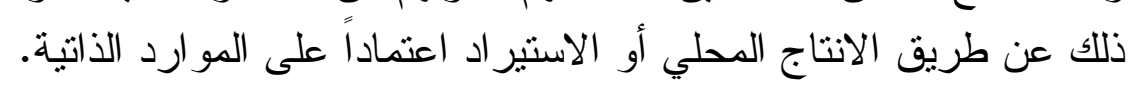

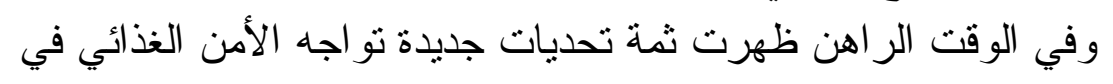
منل هذه المجتمعات خاصة فيما يتعلق بنوعية الغذاء، مرتبطة بالاستخدام

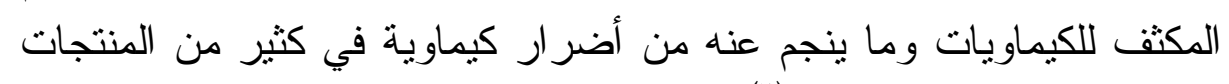

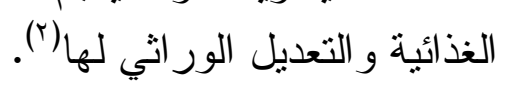

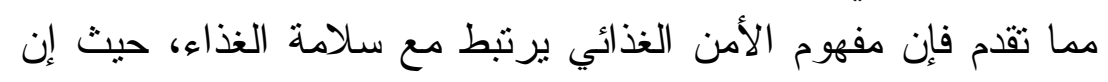

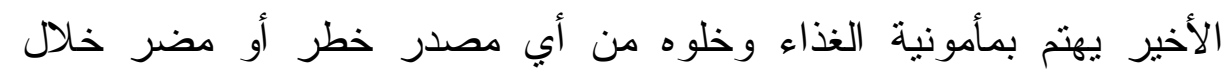

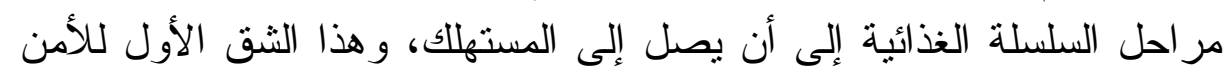
الغذائي بينما يهنم الثق الثاني بالكيفية أو الآلية التي يتم الحصول التيلية من خلالها على الغذاء.

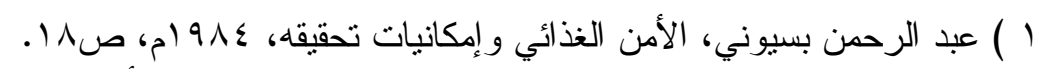

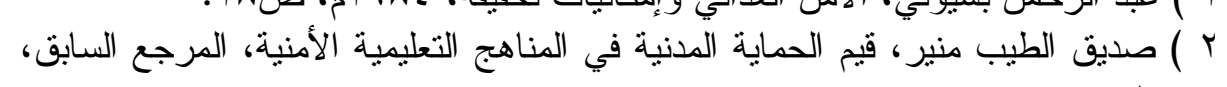




\section{المبمث الثاني}

\section{دور الهينة العامة للغذاء والدواء في هماية سلامة الغذاء}

سوف نتناول في هذا المبحث الثاني دور هيئة الغذاء و الدواء كجهاز

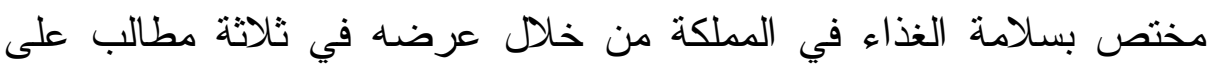

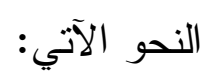

المطلب الأول: دور الهيئة في رسم السياسة الغذائية للمملكة المطلب الثاني: دور الهيئة في تتفيذ السياسة الغذائية للمملكة المطلب الثالث: دور الهيئة الرقابي في حماية سلامة الغذاء

\section{الإلب الأول}

\section{دور الهيئة في رسم العياسة الفذانية}

التزمت المملكة العربية السعودية منذ قيامها بنطبيق الشريعة الإسلامية

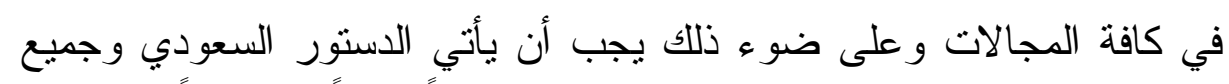

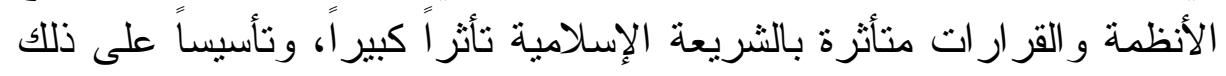
و عند النظر في مو اد النظام الأساسي للحكم تلحظ سمة الإسلام وقو اعده ظاهرة

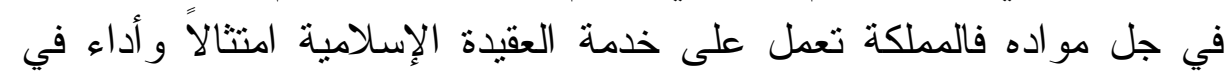

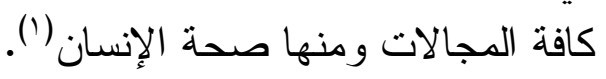
ولما كانت الشريعة الإسلامية تهدف الإنىان الحفاظ الحفاظ على النفس فشرعت

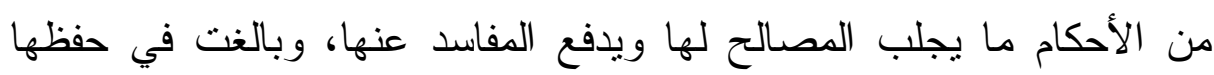

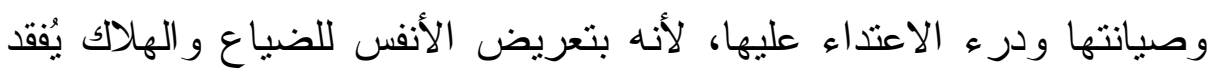
المكلف الذي يتعبد الله سبحانه وتعالى دوره ويؤدي إلى ضياع الدين (؟).

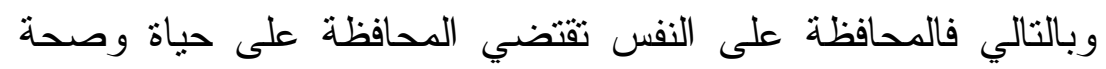

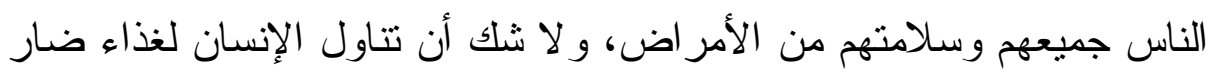

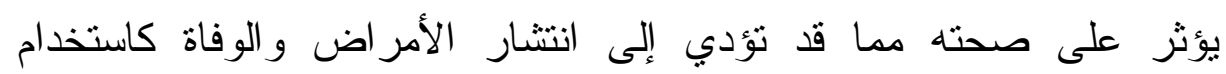
الهرمونات لزيادة الإنتاج وتحسين النوعية كما أن زيادة حجم الثمرة لله تأثير الثراف

(ال) خالد عبد اله الثافي، مبادئ النظام الدستوري في المملكة العربية السعودية، الطبعة

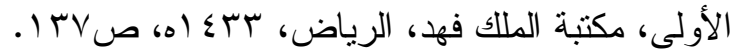

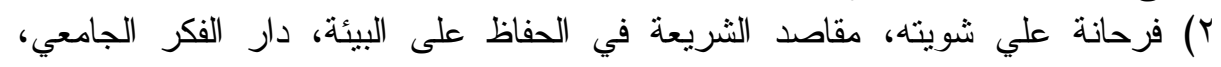

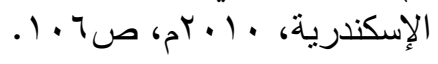


ضار على صحة الإنسان، بالإضافة إلى الأثر المنبقي للهرمونات في الخضار

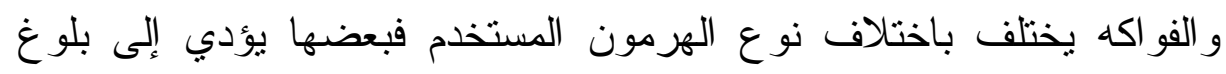

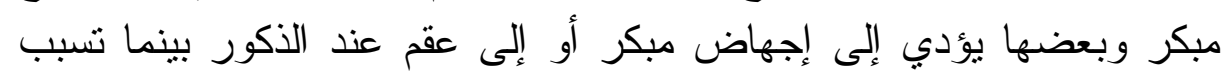

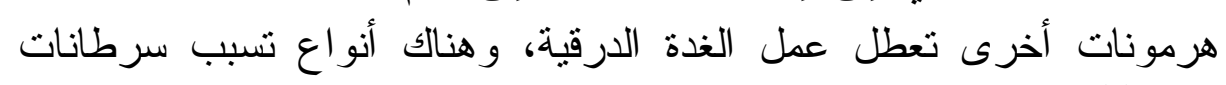
عديدة) (1). (1)

ولما كانت الهيئة العامة للغذاء و الدواء بالمملكة هي الجهة المعنية بالحفاظ على الإنسان وصحته بشكل عام ومر اقبة كل ما يؤثر فيها، وتحديداً سلامة غذائه(r)، فإن المنظم أناط بالهيئة رسم السياسة الغذائية للمملكة، و واسند

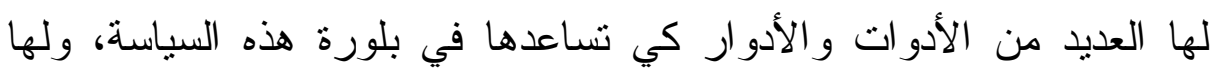
على سبيل المثال لا الحصر الآتي (r):

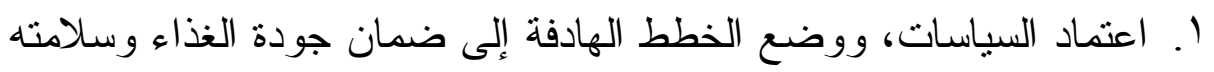
في المملكة، وذلك بالتتسيق مع الأجهزة الحكومية الأخرى المعنية بالأمر كوز ارة الصحة و غير ها.

ץ. مر اجعة الأنظمة و اللوائح الرقابية ذات العلاقة بمجال عملها، وتطويرها

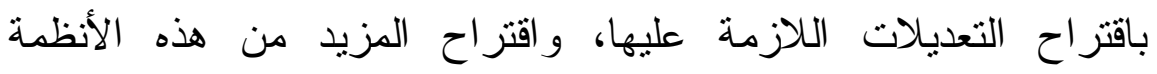

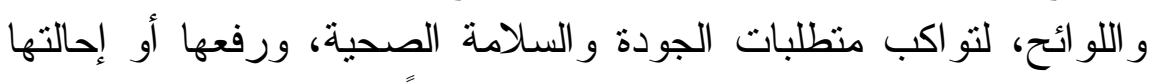

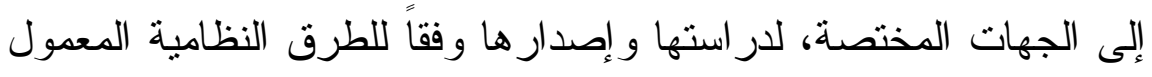
بها.

r. وضع مواصفات قياسية إلزامية لأغذية، والمستحضرات الحيوية الصحية، و النباتات و الاعشاب التي لها ادعاء طبي، و الكو اثف الثفية التخبرية

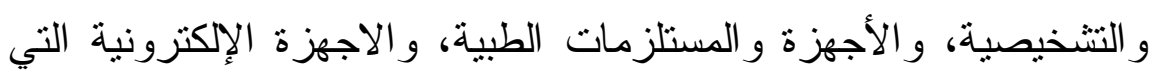
تؤثر على صحة الإنسان و المبيدات.

ع. وضع الأسس السليمة للتصنيع الغذائي والدوائي والاشتز اطات الصحية الو اجب ثو افرها في المر افق و المصانع على النحو النالي: المنشآت الغذائية

( ) إير اهيم حسن، الإسلام و البيئة، المجلس الأعلى للثؤون الإسلامية، صبهام.

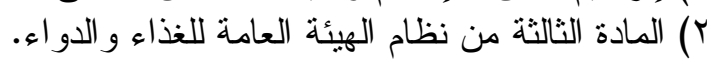

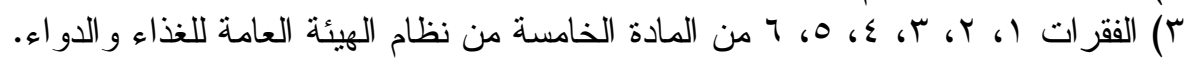


و العاملين فيها، مرافق ومصانع المياه، مرافق الصناعات الدوائية

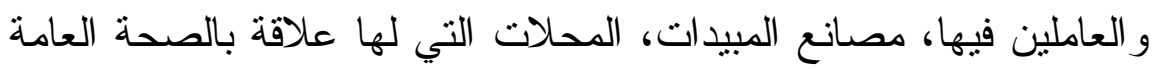
وتدخل ضمن اختصاصات الهيئة.

○. وضع الضو ابط و الإجر اءات الني تتظم عمليات فحص المنتجات الغذائية،

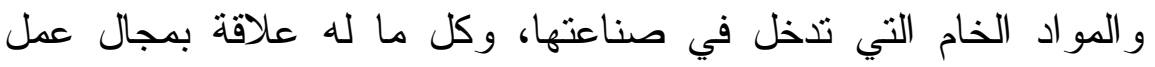
الهيئة، و الإعلان عن هذه المنتجات و واستير ادها و وتصدير ها، و وأعمال

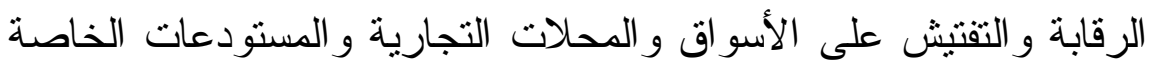
بهذه المنتجات، وذلك بالتعاون و التتسيق مع الجهات ذات التهو العلاقة.

T. إعداد تطوير البرامج التدريبية الكفيلة برفع كفاءة العاملين في مجال عمل

الهيئة.

ويرى الباحث من خلال منطلقات عمل الهيئة العامة للغذاء و الدواء

التي تلخيص السياسة الغذائية للمملكة في ثناثة محاور : ضمان سلامة ماندة الغذاء

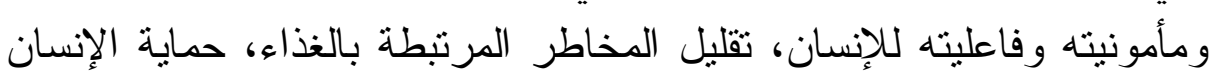
من الغذاء الضار أو المغشوش.

\section{الاطبا الثاني}

\section{دور العينة في تنفيذ المياسة الغذابية للمبماكة}

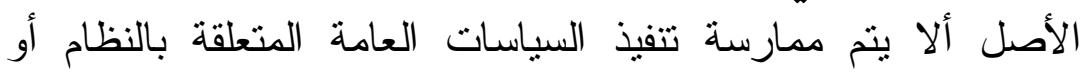

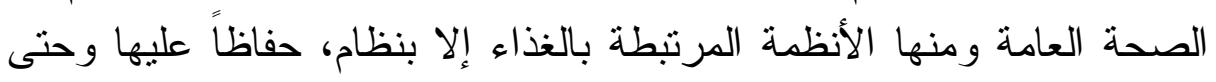

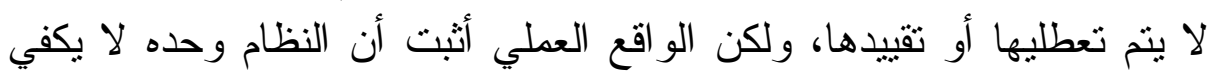

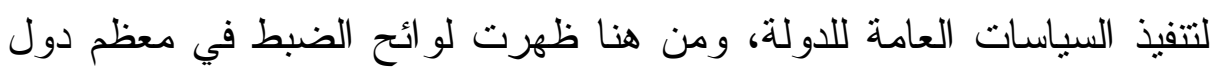
العالم كأسلوب وقائي لإكمال النقص النظامي وتنفيذ السياسات الغذائية

للمملكة (1) (1)

أولاً: إصدار لوائح تنفيذية:

تتمتع الهيئة العامة للغذاء و الدواء في سبيل تتفيذ السياسات الغذائية

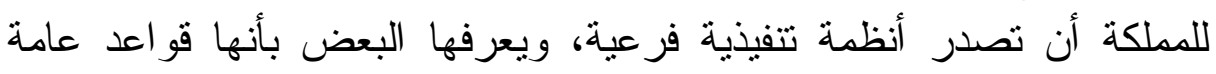

(1) محمد شريف اسماعيل، سلطات الضبط الإداري في الظروف الظعاف الاستثائية، رسالة

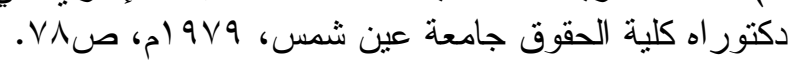




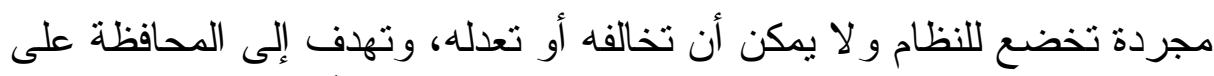

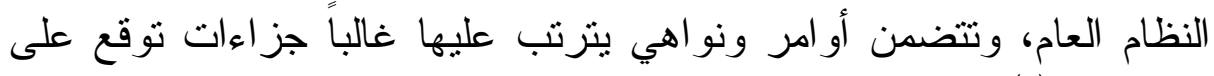

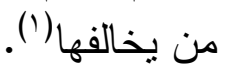

ومن أمنلة لوائح الضبط التي تصدرها الهيئة ما قررته المادة الر ابعة

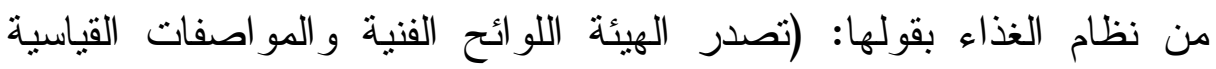
للغذاء، ومر افقه، و العاملين فيها) وكذلك المادة التاسعة و العشرون من النظام

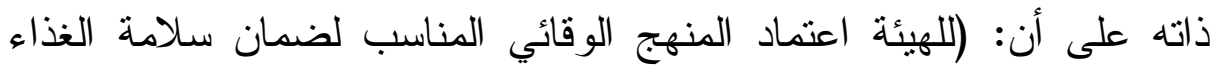
خلال مر احل السلسلة الغذائية، ولها في سبيل ذلك فرض النهاد النظم الفنية الكفيلة

$$
\text { ثتانياً: إصداره). }
$$

يحق للهيئة أن تصدر القرار فرده: الفرات الفردية للمحافظة على النظام العام

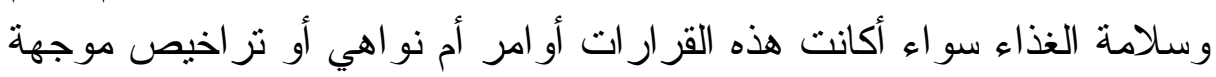

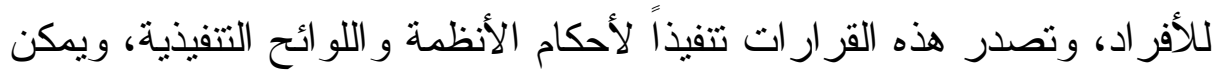

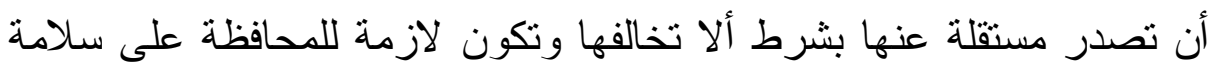

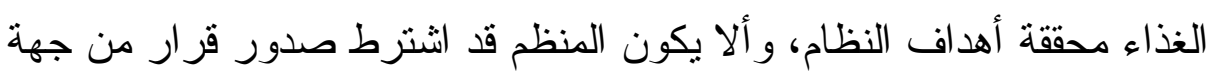

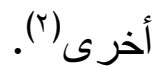

ومن أمتلة هذه القرارات ما نص عليه نظام الغذاء، في حالة إذا ما

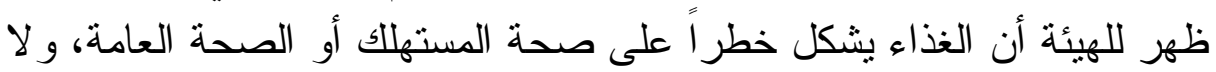

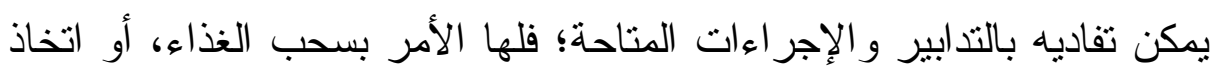

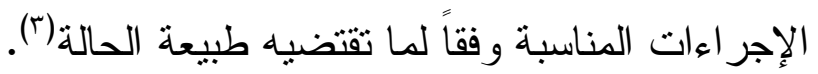

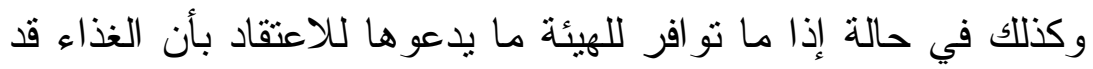

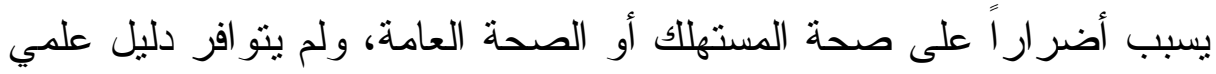

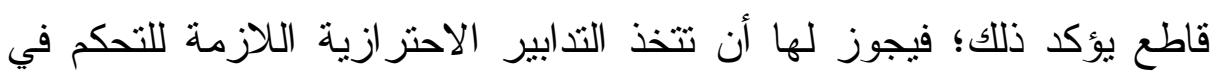

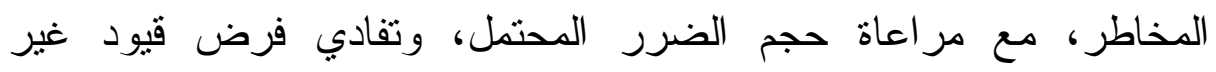

(1) محمد الوكيل، حالة الطو ارئوسلطات الضبط الإداري - دراسة مقارنة، الطبعة الثانية،

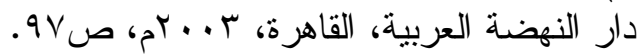
r أثرف هلال، الموسوعة الجنائية البيئية من الناحية الناحية الموضوعية والإجرائية، نادي

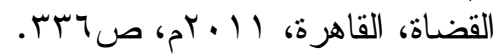
r) المادة الثانية و الثلاثون من نظام الغذاء. 
ضرورية، ومراجعة نلك التدابير خلال مدة معقولة في ضوء نتائج تقويم (1) (1) (1) ثالثاً: استخدام القوة المادية: يجوز للهيئة استخدام القوة المادية - دون الحاجة للجوء إلى القضاء و إجر اءاته البطيئة، لمنع وقوع أية أخطار أو في حالة تعرض صحة وسلامة الغذاء للخطر ، وإجبار الأفر اد على احتر ام أحكام أنظمة الغذاء، و القرارات اته المنفذة له، فيجوز للهيئة أن تلجأ إلى أو امر ها على الأفر اد بالقوة الجبرية دون الحاجة إلى إذن سابق من القضاء، و هو ما يسمى بالتتفيذ المباشر وهو طريق

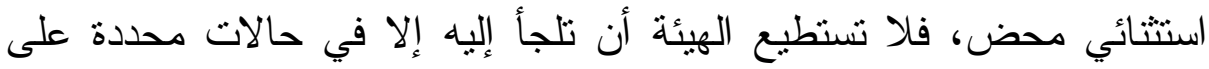
سبيل الحصر ، فلا يجوز للهيئة أن تلجأ إلى هذه الوسيلة إلا في حالتين: ا . الحالة الأولى: إذا وجد نص في النظام يبيح للهيئة اتخاذ هذا الطريق. ץ. الحالة الثانية: هي حالة الضرورة ومقتضاها أن تجد الهيئة نفسها أمام خطر داهم يقتضي التذخل فور اً للمحافظة على الأمن وسلامة الغذاء.

وبالرجوع لنظام الغذاء يتضح أنه قضى بأنه للهيئة إذا كان هناك خطر محتمل يهدد صحة المستهلك أو الصحة العامة في منشأة غذائية، أو مر افقها، أو أيِّ محتوياتها، أو منتجاتها؛ أن تصدر أمراً بإغلاق هذه المنشأة أو أي من مر افقها وفقاً للإجر اءات التي تحددها اللائحة (r).

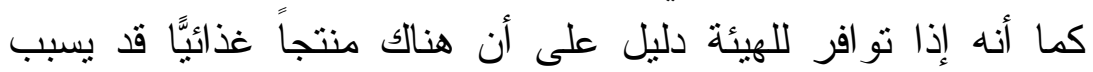
ضرراً على صحة المستهلك، أو الصحة العامة؛ فلها الأمر بسحب المنتج، أو أو استرجاعه ومنع تداوله وفقاً للإجر اءات التي تحددها اللأيحة(r). و أيضاً للهيئة أن تأمر إداريًّا بإتلاف أي منتج غذائي مخالف لأحكام هذا النظام ولو ائحه متى كان تداوله بسبب ضرراً على صحة المستهلك أو الصحة العامة، وتحدد اللائحة إجر اءات الإتلاف (ء).

( ) المادة الثلاثتون من نظام الغذاء.

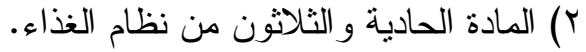

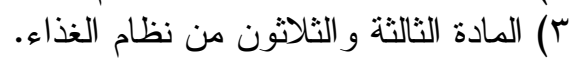
ع) المادة الر ابعة و الثنالثون من نظام الغذاء من نظام الغذاء. 
و الجدير بالذكر أنه تقرر بموجب نظام الغذاء إنشاء نظام إنذار سريع

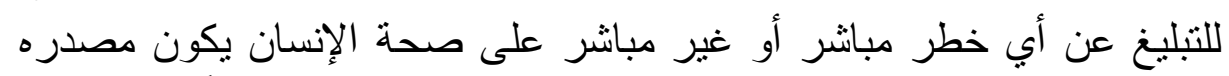

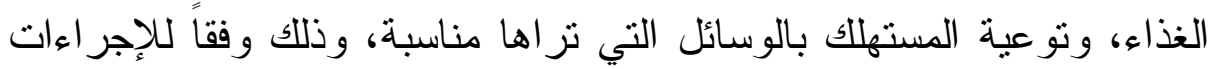
التي تحددها اللائحة، يدار من خلال الهيئة (').

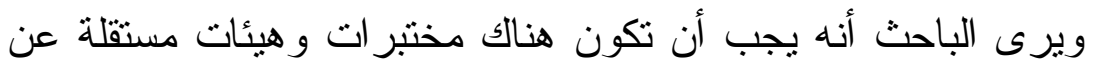

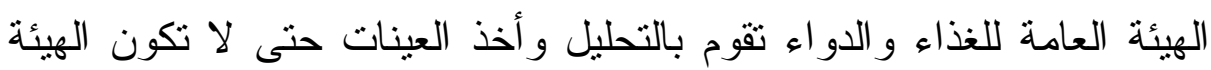
هي الخصم و الحكم في الوقت ذاته، كما يجب أن يكون موظفو التهاء هذه الجهات

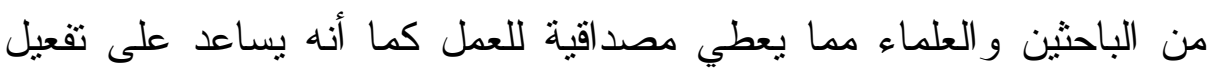

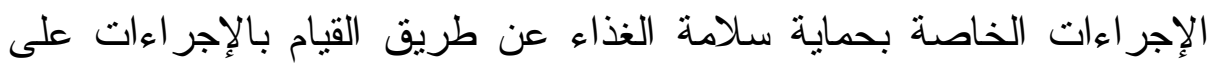

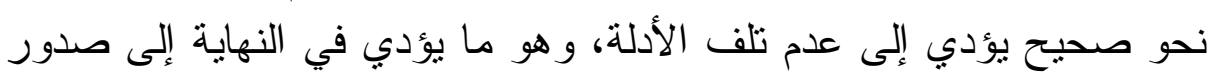
أحكام ضد المخلفين.

\section{الإلب الثالث}

\section{دور الميئة الرقابي في هماية سلامة الغذاء}

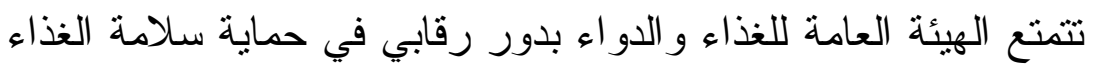

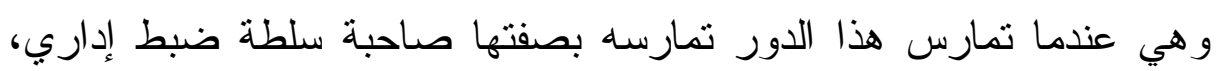
و عندما يتبين لها وقوع مخالفات فنتنقل بذلك لسلطة الضبط القضارئ هذائي.

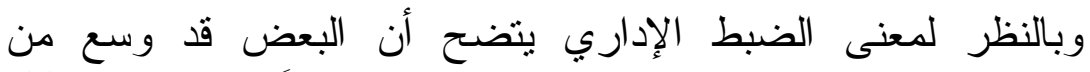

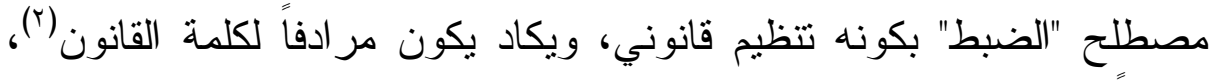

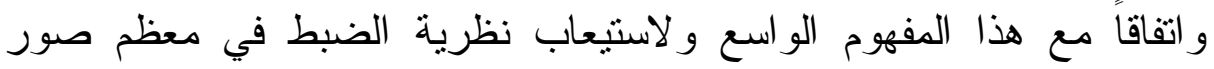
النشاط الإداري تم تعريف الضبط بشكل عام بأنه التنظيم الذي تقوم به الدولة

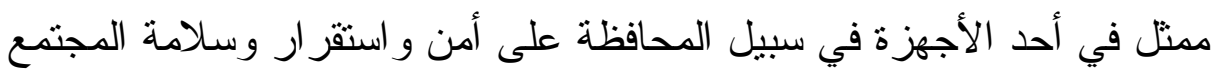

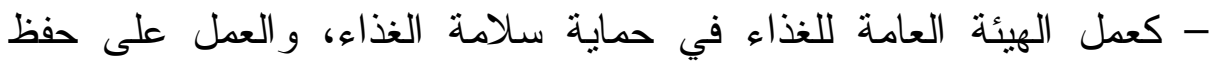

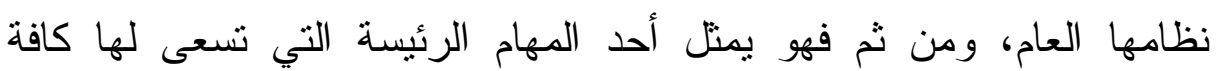

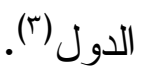

( ) المادة الحادية و العشرون من نظام الغذاء.

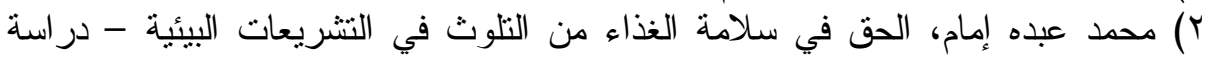

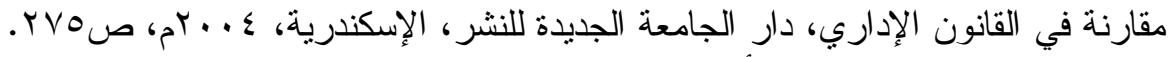

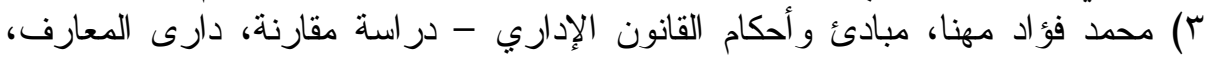

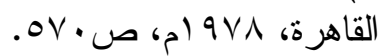


و هذا التنظيم المحدد من قبل الدولة والذي يطلق عليه نظام الضبط،

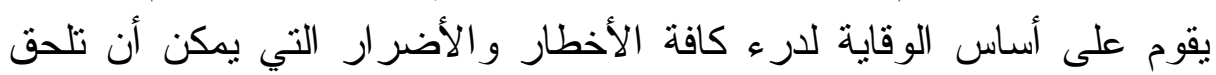

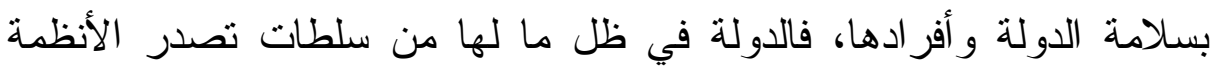

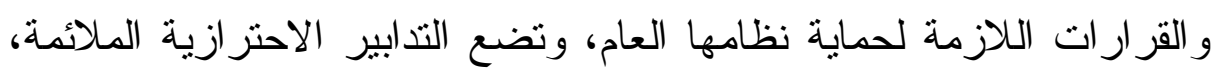

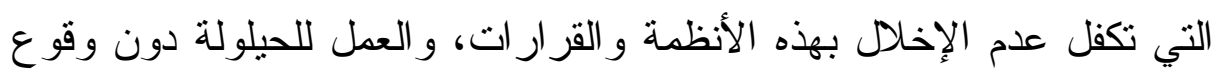

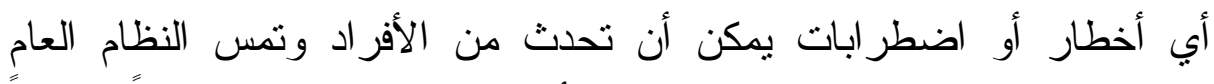

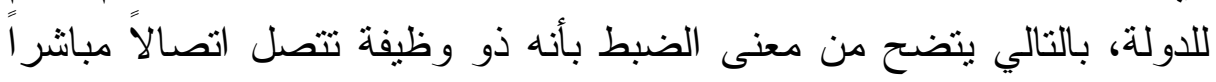

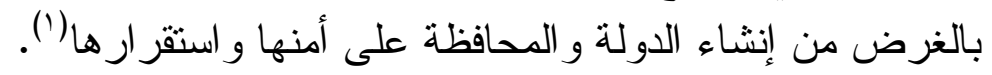
بينما ضيق البعض من معنى الضبط الإداري وذهب إلى الى أن مفهوم

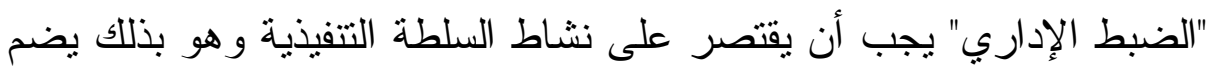
النشاط الذي تتو لاه الهيئات الإدارية (ممثل في أحد أجهزتها كالهيئة العامة للغذاء)، ويتمثل في تقييد النشاط الخاص بهدف صيانة النظام العام - الذي لإدي يتمثل في الحفاظ على صحة أفر اد المجتمع من الأمراض بتقديم غذاء سليم وصحي (r) (ب)

بالرجوع لنظام الغذاء يتضح أن الهيئة العامة للغذاء و الدواء لها آلها

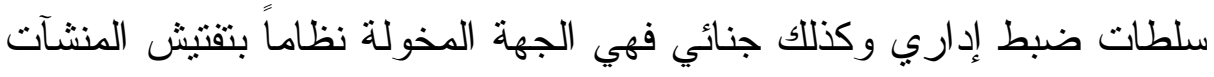

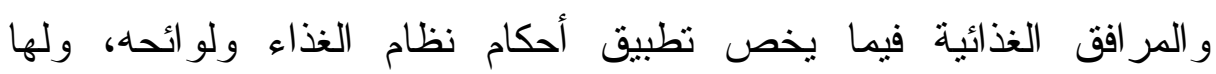

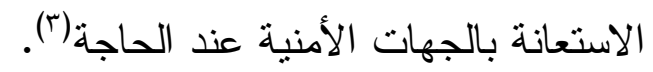

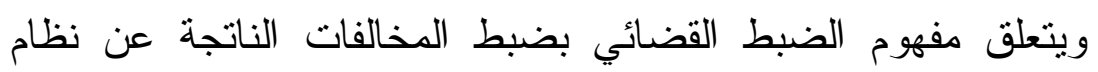

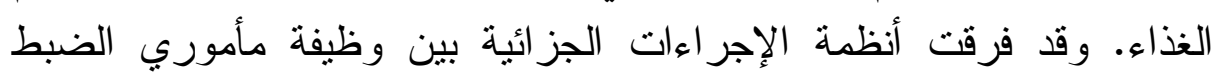

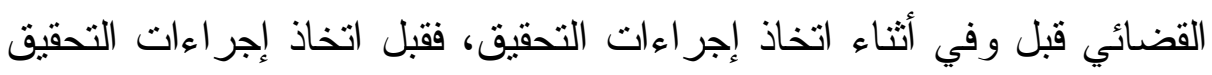
تكون مهمة مأموري الضبط القضائي البحث عن الجرائم ومرتكبيها وجمع إهى

( ) أثرف هلال، الموسوعة الجنائية البيئية من الناحية الموضوعية والإجرائية، المرجع

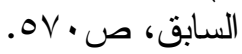
r) محمود عاطف البنا، حدود سلطة الضبط الإداري، دار الفكر العربي، القاهرة، .91 ام، ص r) المادة الثانية و العشرون من نظام الغذاء. 
الأدلة، أما في أثناء اتخاذ إجراءات التحقيق تكون مهمة مأموري الضبط القضائي تتفيذ ما تتندبه فيه سلطات التحقيق و الانصياع لأو امرهم (').

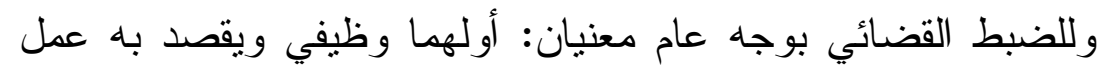

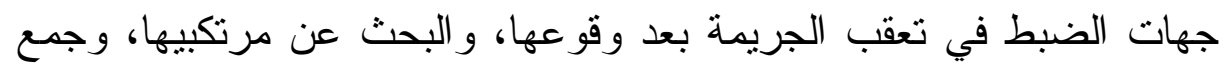
الاستدلالات اللازمة لإثبات التهمة عليهح أو اتخاذ ما يلزم من فئه الاحتياطات

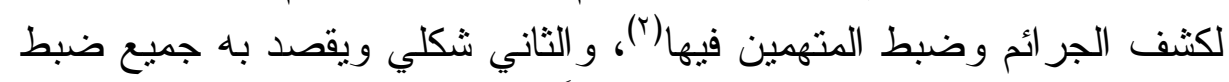

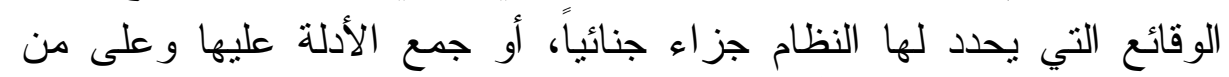

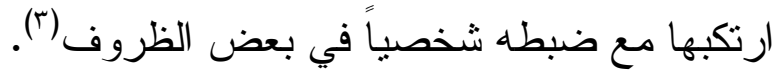

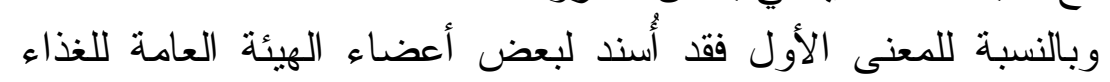

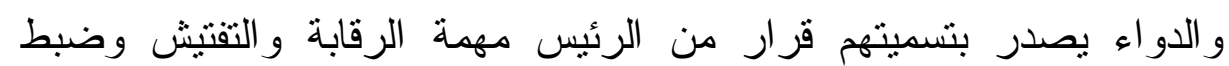
مخالفات نظام الغذاء، وتكون لهم صلاحيات وسلطات مأموري الضبط

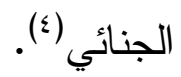

ويجب على المفتش إبراز بطاقة هويته الوظيفية عند دخول المنشآت و المر افق الغذائية لغرض التفتيش، وله الاطلاع على المستتدات و السجلات

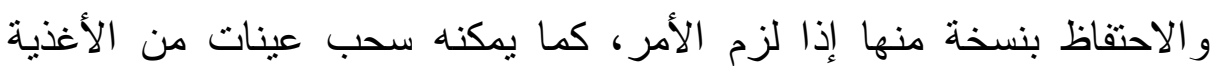
لتحليلها. و على المنشأة أو المرفق الغذائي تمكينه من ذللك، و وعدم إعاقته (०). و إذا ظهر للمفنش وجود غذاء مخالف لأحكام هذا النظام أو لو ائحه؛

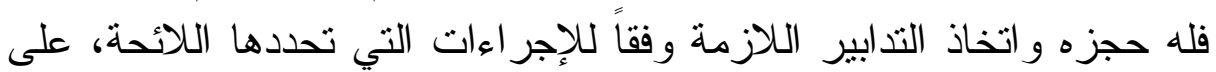

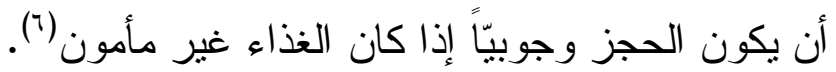

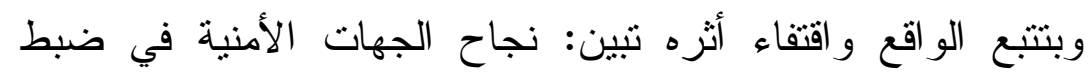
و اتلاف شحنة دجاج فاسدة احتوت على أكثر من لـ . . ألف دجاجة منتهية

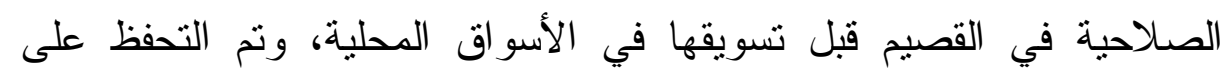

() حسن صادق المرصفاوي، المرصفاوي في أصول قانون الإجراءات الجنائية، منشأة

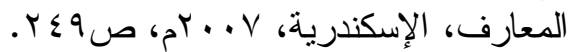

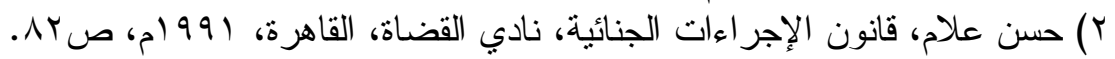

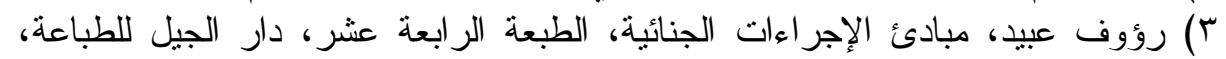

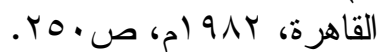
ع) المادة الثالثة و العشرون من نظام الغنام الغذاء. 0) المادة الر ابعة و العشرون من نظام من نظمام الغذاء. 7) المادة الخامسة و العشرون من نظام الغذاء. 
المضبوطات، وتم تشكيل لجان من مشروع دو اجن الوطنية للبحث عن طريقة

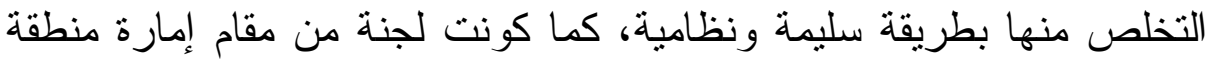

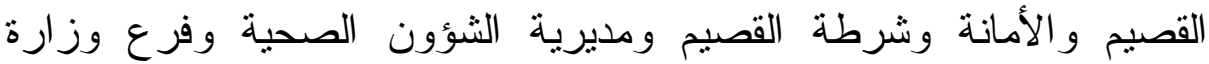
التجارة و الاستثمار و إدارة الطرق و النقل للتحقيق بهذه الضبطية (').

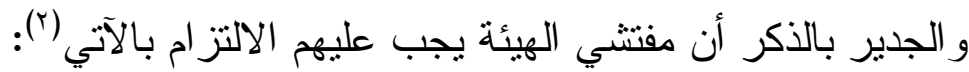

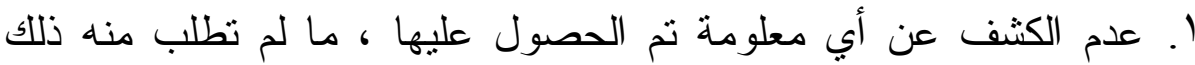
الهيئة أو المحكمة المختصة. r. التقبد بالأحكام و الإجر اءات المنصوص عليها في نظام الغذاء ولو ائحه. r. تحرير محضر ضبط إذا كانت هناك مخالفة لأحكام هذا النظام ولو ائحه، تسلم نسخة منه للمخالف.

\section{المبهث الثالث}

\section{استزاتيمية نظام الغذاء في تمقيق سلامة الغذاء وجودته}

سوف نتناول في هذا المبحث الثالث استر اتيجية نظام الغذاء في تحقيق

سلامة الغذاءو جودنه من خلال عرضه في ثلاثة مطالب على النحو الآتي:

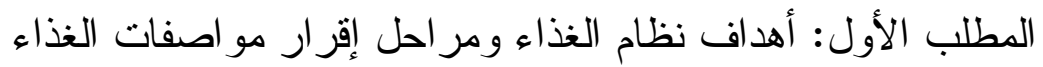

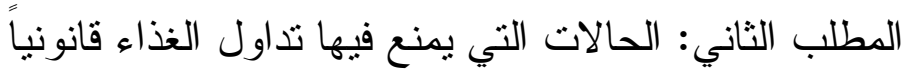
المطلب الثالث: العقوبات القانونية لمن يعرض سلامة الغذاء لغذاء للخطر

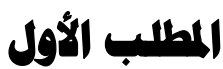

\section{أهداف نظام الغذاء وهراصل إقرار هواصفات الغذاء}

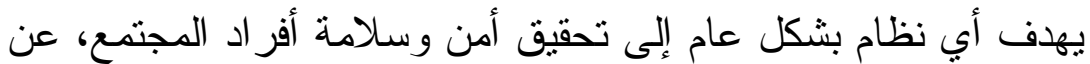
طريق الوسائل اللازمة لمنع أي اعتداء على حقوق و أعضاء المجتمع فيما بين

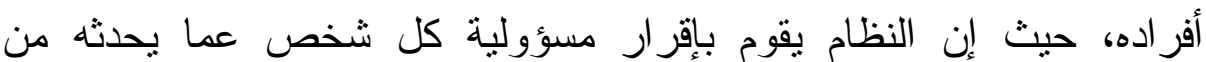

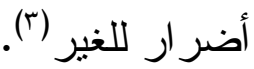

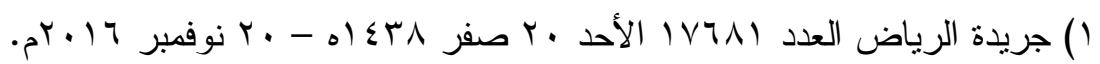

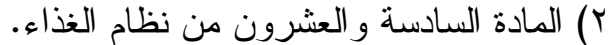

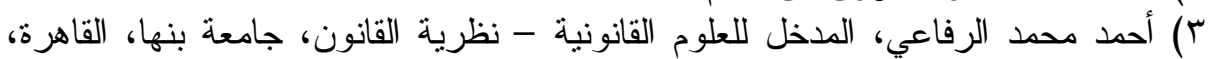

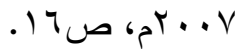


بالإضافة إلى الاهداف العامة السالف ذكرها فإن لنظام الغذاء أهداف

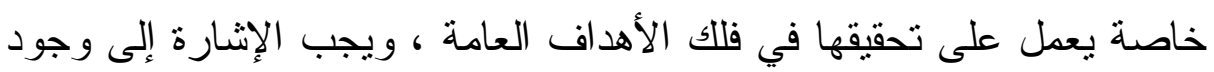

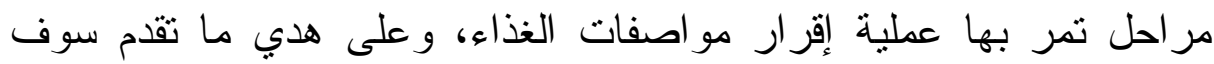

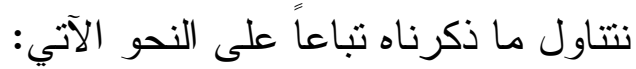

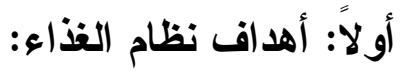

وضع المنظم أهداف ينبغي على نظام الغذاء تحقيقها، وهي ('): ا ا ـ ضمان سلامة الغذاء وجودنه:

لكي تتحقق الحماية القصوة للمستهلك يجب إدخال مبادئ الجودة في

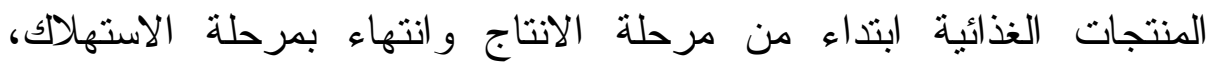

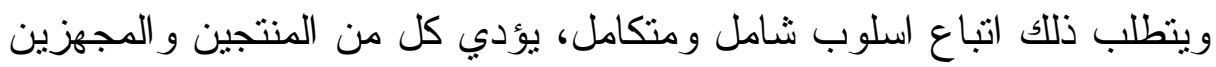

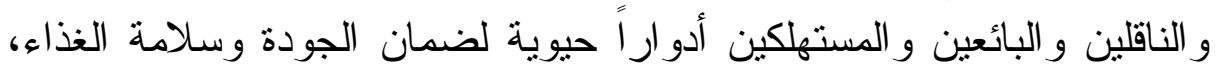

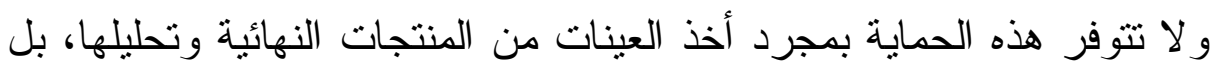
يجب إدخال التدابير الوقائية في جميع مراحل سلسلة الانتاج و التوزيع، بدلاً

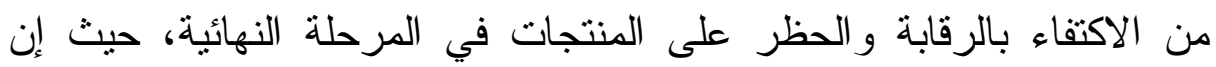
المنتجات غير السليمة يمكن التعرف عليها منذ بداية السلسلة الغذائية(؟).

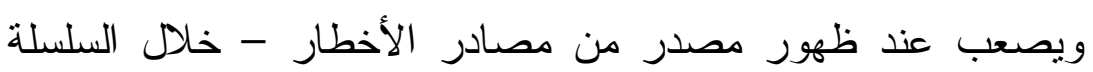
الغذائية - اختباره لارتفاع تكاليف ذللك، إلا أن الطريق الأفضل هو الإند التباع

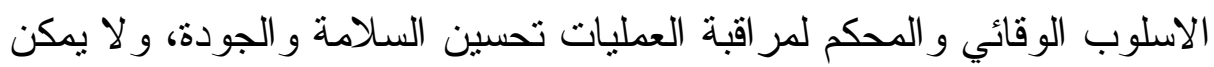
تجنب كل الاخطار ولكن من المكن تجنب معظمها في السلسلة الغذائية بفضل تطبيق الممارسات الجيدة.

ومن الاساليب الوقائية المهمة التي يمكن تطبيقها في جميع مراحل انتاج الأغذية وتجهيزها وتتاولها هو نظام تحليل الأخطار في نقاط الرقابة الحرجة، ولهذا النظام مبادئ رسمية وضعتها لجنة الدستور الغذائي المعنية بسلامة الغذاء، لكي يساعد في التعرف على الأخطار التي تتقلها الأغذية رلية

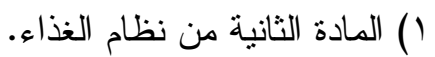

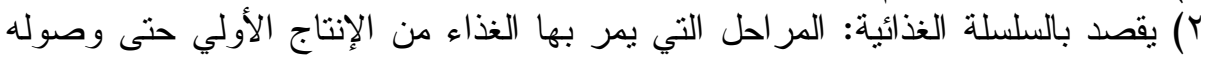

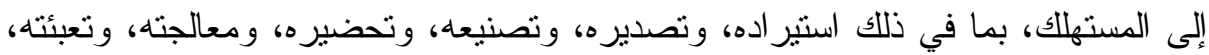

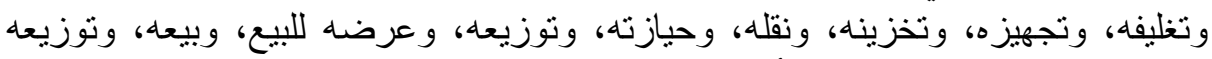

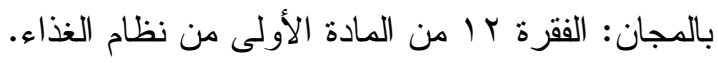


ومكافحتها ، وينبغي أن تعترف الدول بأن تطبيق هذا النظام من جانب

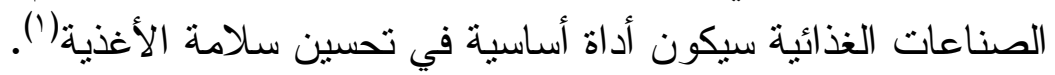
و على صعيد المملكة فقد عمل نظام الغذاء على إيجاد نظام إنذار سريع للتبليغ عن أي خطر مباشر أو غير مباشر على صحة الإنسان يكونٍ

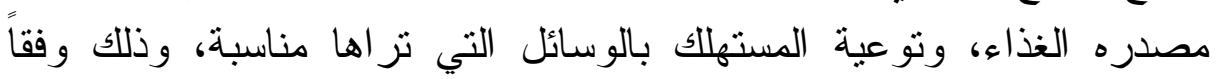

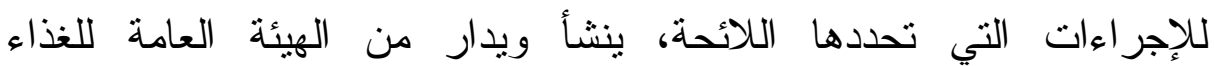
و الدو اء) (r) r. حماية الصحة العامة للمستهلك:

تهتم المملكة العربية السعودية بحماية الصحة العامة للمستهلك، من

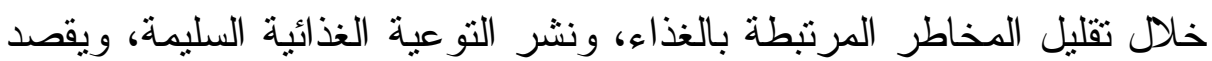

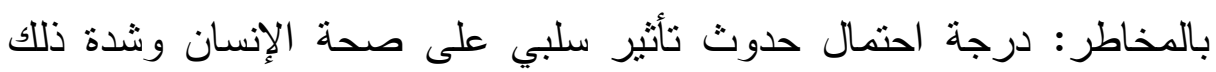

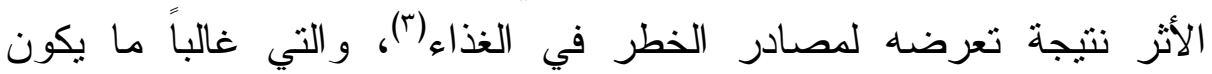

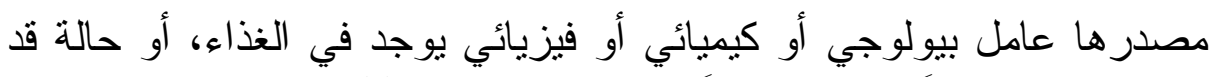

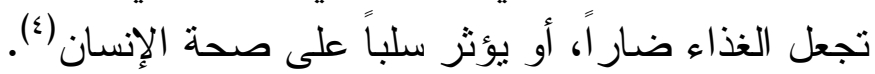
وتستخدم الهيئة العامة للغذاء و الدواء أسلوب تحليل الإنسان المخاطر و الذي لهي يعني نهج علمي يهدف إلى تقويم مدى خطورة الغذاء وطريقة التحكم في

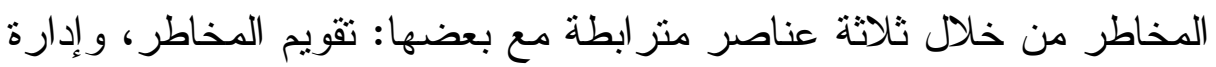

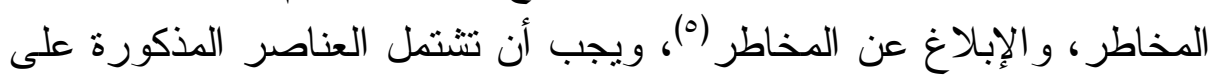
معلومات معينة هي: احتمال تواجد تللك الأخطار ودرجة خطورتها على الإبلى

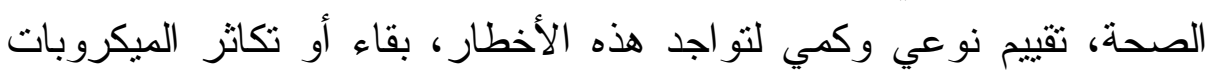

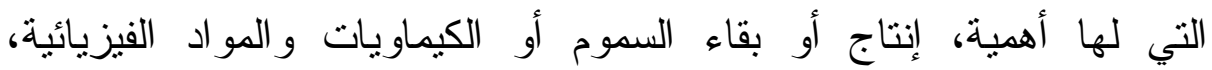

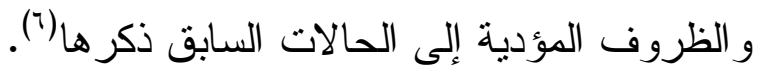

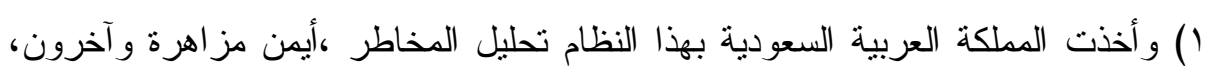

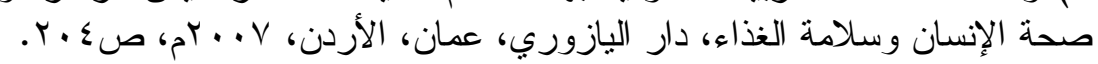
r) المادة الحادية و العشرون من نظام الغذاه الغذاء.

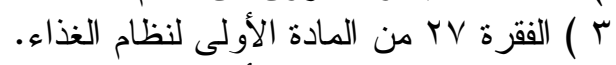

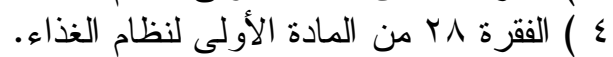

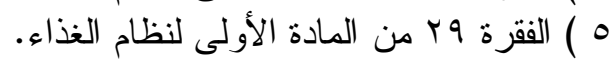

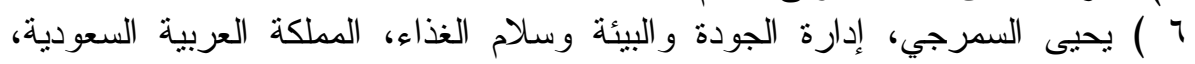

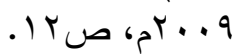


r. حماية المستهلك من الغذاء المغشوش:

استهدف نظام الغذاء حماية المستهلكين من الغش في الأغذية، أو

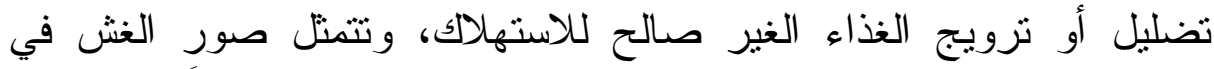

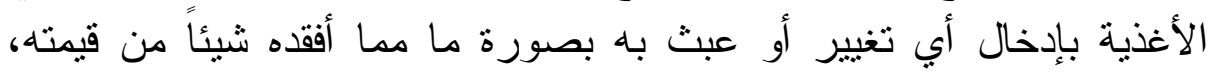

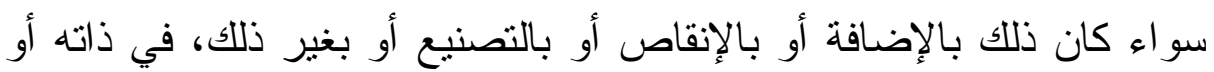

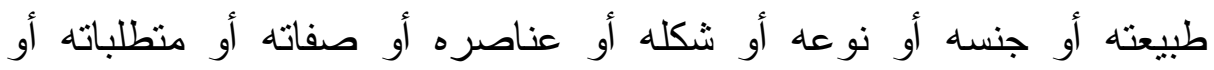
خصائصه أو مصدره أو قدره سواء في الوزن، أو الكيل، أو المقاس، أو أو أو أو أولاته العدد، أو الطاقة، أو العبار ('). وفي هذا المقام يلح تساؤل هام وهو هل تعتبر الأغذية غير المطابقة

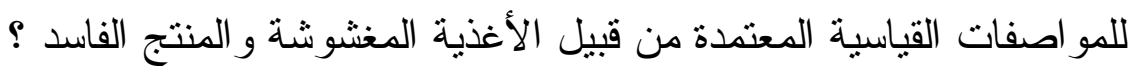

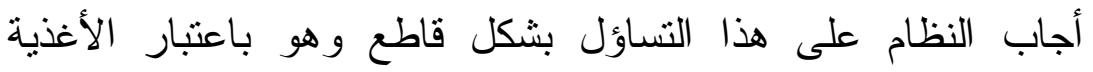
المذكورة ضمن الأغذية المغشوشة فكل منتج غير مطابق للمو اصفات القياسية

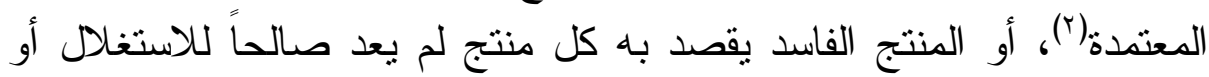

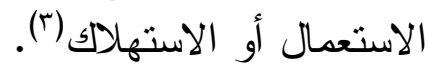

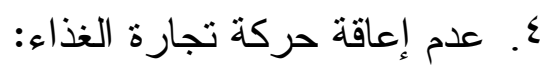

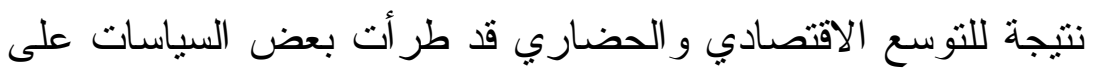

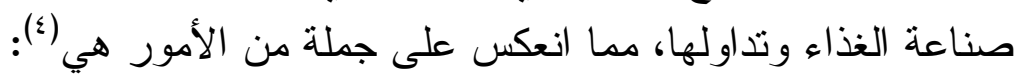

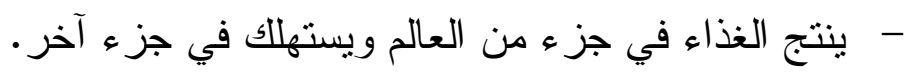

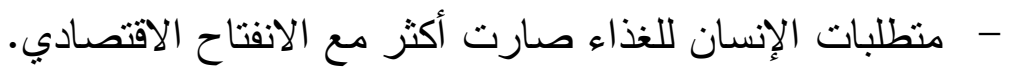

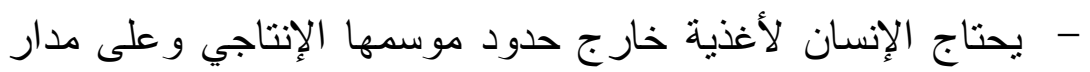
العام.

- يحتاج الإنسان الوجبات السريعة والخفيفة بعيداً عن المنازل.

( ) فقرة أ من المادة ا من نظام أمار مكافحة الغش التجاري الصادر بالمرسوم ملكي رقم: ( )

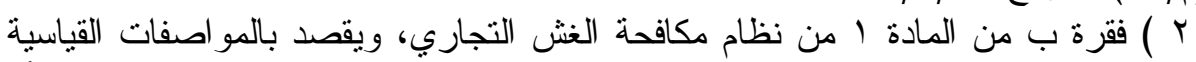

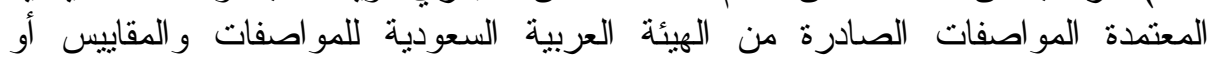

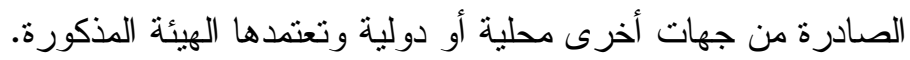

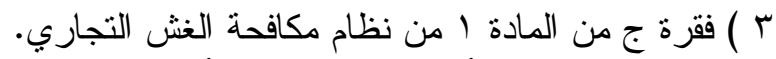

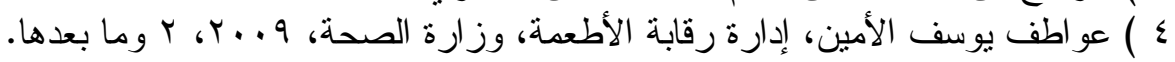


و إذا أخذنا في الحسبان ضرورة الاهتمام بجودة وسلامة الغذاء، فإن

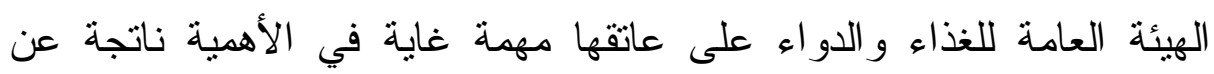

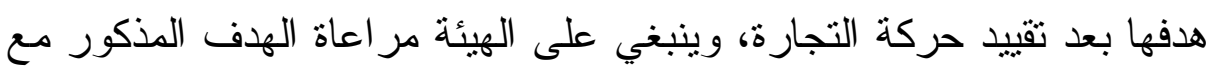
مر اعاة الحفاظ على صحة وسلامة الغذاء.

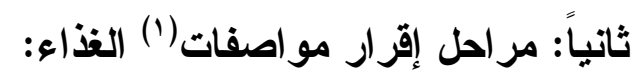

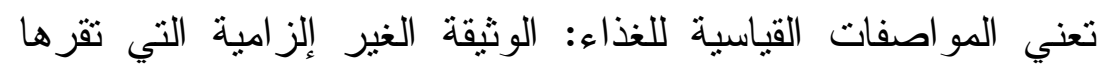

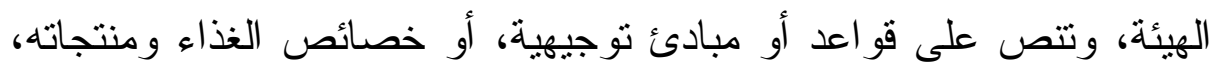

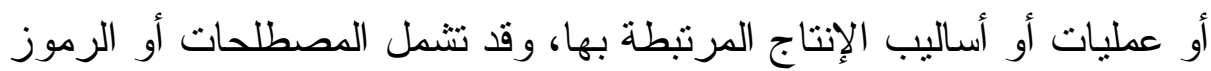

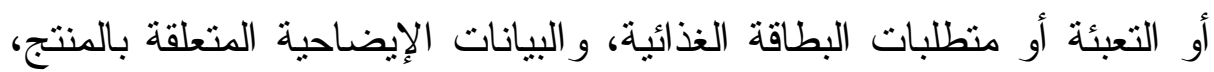
أو طريقة إنتاجه(؟)، وهي بذلك تختلف عن اللو ائح الفنية: التي يقصد بها وثائق الإنق إلز امية تصف خصائص الغذاء أو طرق إنتاجه وتصنيعه، و التعليمات المنظمة فئهة

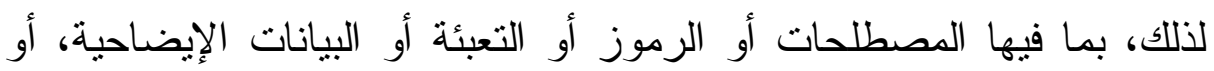
البطاقة الخاصة بالمنتج، أو طريقة إنتاجه (). تتبنى الهيئة - في سبيل اعتماد اللوائح الفنية و المواصفات القيات القياسية

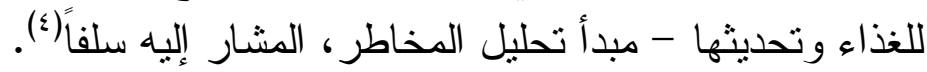

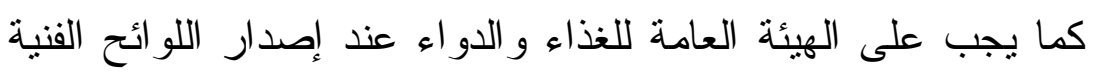
و المواصفات القياسية للغذاء وتحديثها مراعاة المواصفات القياسية الدولية للغذاء (0).

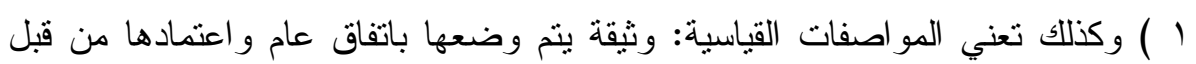

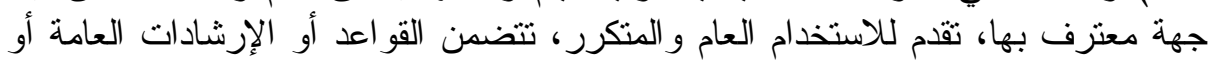

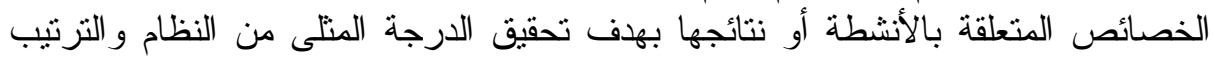

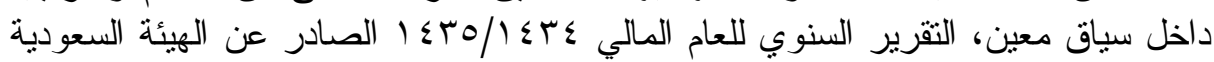

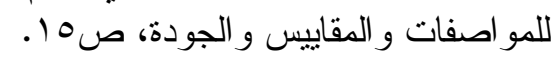

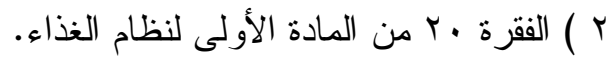

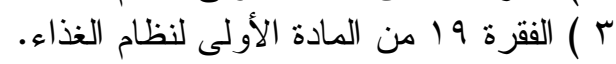

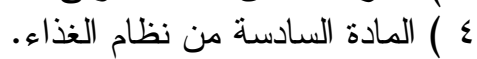

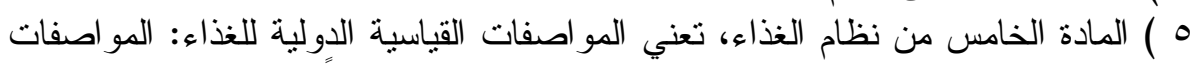

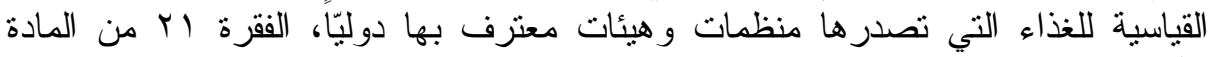
الأولى لنظام الغذاء. 


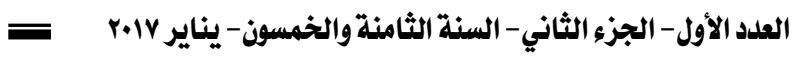

ويجب على الهيئة أن تعرض مشاريع اللوائح الفنية و المواصفات

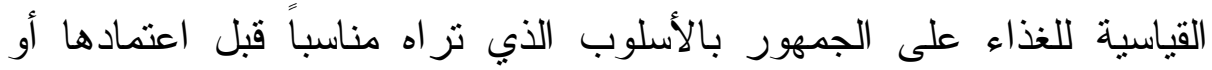
إصدار ها؛ وذلك لتلقي الملحوظات و المقترحات (').

\section{الاطبا الثاني}

\section{المالات التي يمنه فيها تداول الغذاء قانونيا}

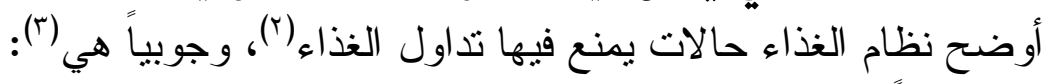

$$
\text { ا ـ إذا كان مخالفاً لأحكام الثريعة الإسلامية. }
$$

r. إذا كان ضار اً بالصحة أو غير صالح للاستهلاك.

r. إذا كان مخالفاً للو ائح الفنية أو المو اصفات القياسية للغذاء.

ع. إذا كان مغشوشاً، أو يحتوي على طرق أو وسائل مخادعة أو ممارسة تضلل المسترلك.

๑. إذا لم يكن معبأ بالطريقة التي تحددها اللوائح الفنية، عدا ما يتم استثناؤه في الكائحة.

T. إذا لم ترفق به البطاقة الغذائية و البيانات الإيضاحية، عدا ما يتم استثناؤه

$$
\text { في اللائحة. }
$$

$$
\text { V. إذا لم يكن مسجلاً لدى الهيئة. }
$$

وفي حالة تحقق حالة من الحالات السابقة يجب سحب الغذاء طبقاً للإجر اءات أو التدابير التي تتخذ لاستعادة حيازة الغذاء غير المأمون للمستهلك لهن

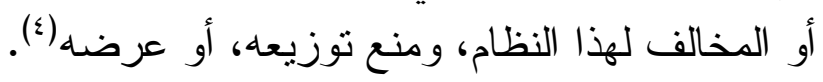

( ) ) المادة الثانية و الأربعون من نظام الغذاء.

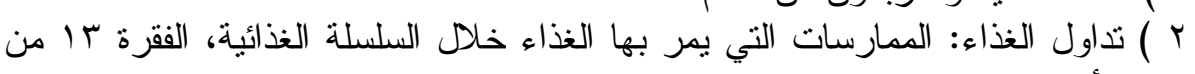

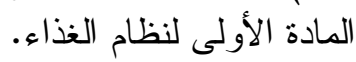

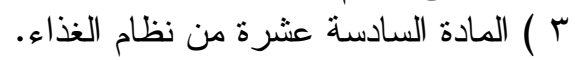
ع ) الفقرة الب من المادة الأولى لنظام الغذاء. 


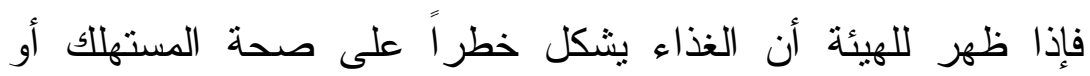

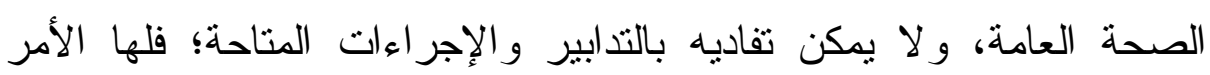

بسحب الغذاء، أو اتخاذ الإجر اءات المناسبة وفقاً لما تقتضيه طبيعة الحالة (').

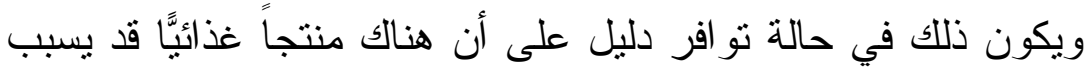

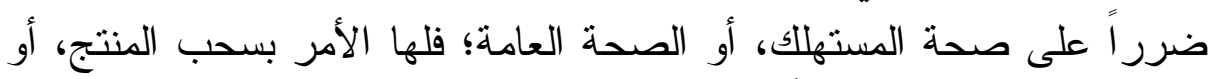
استرجاعه ومنع تداوله وفقاً للإجر اءات التي تحددها اللائحة (؟).

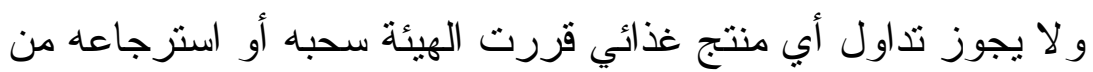

$$
\text { السوق، أو حظر تداوله لَّ). }
$$

\section{الإطب الثالث}

\section{العقوبات القانونية لمن يمرض سلامة الغذاء للفطر}

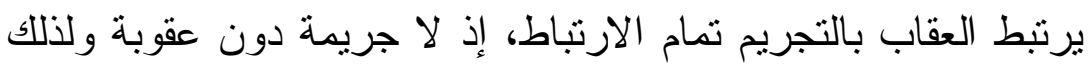

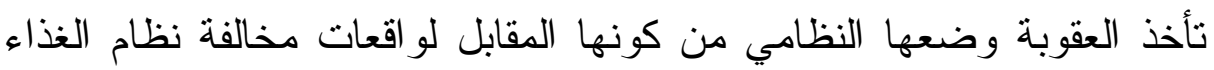
المجرمة بموجبه، ويتمثل مضمون العقوبة في الأثز الذي يلحق بالمحكوم

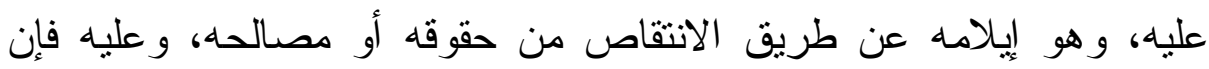
العقوبة هي الأثز الذي ينص عليه النظام ليلحق المجرم بسبب الني ارتكابه

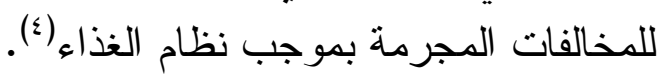

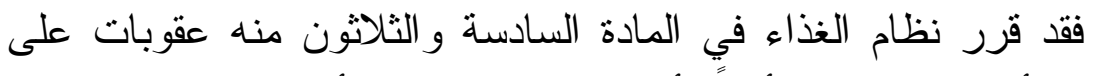

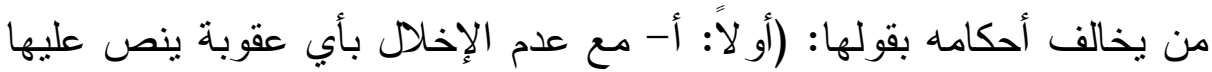

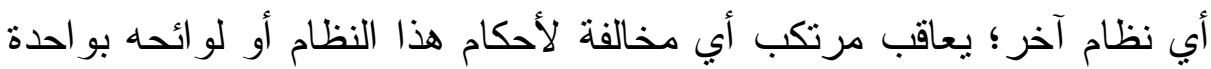

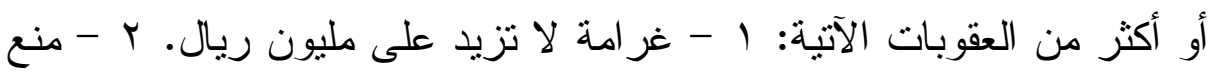

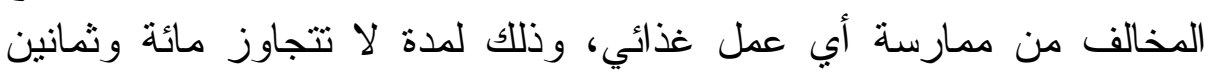

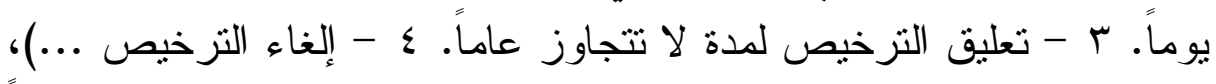
وقد شدد النظام العقاب في حالة ما إذا كانت المخالفة تتمنل في التسبب عمداً بتداول مادة غذائية ضارة بالصحة أو مغشوشة أو ممنوعة؛ فتكون العقوبة الصابة

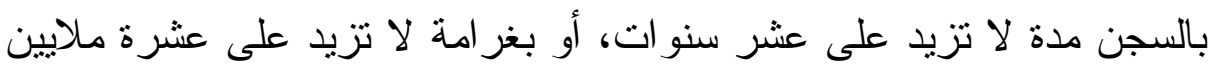

( ) المادة الثانية و الثلاثتون من نظام الغذاء.

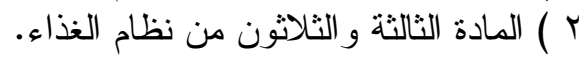

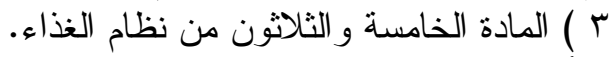

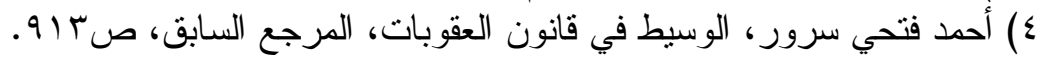


ريال، أو بهما معاً، بالإضافة إلى تطبيق أي من العقوبات المنصوص عليها

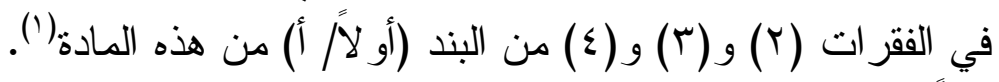

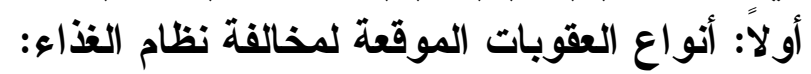
تتقسم العقوبات الموقعة بالمخالفة لنظام الغذاء إلى عقوبات أصلى أصلية، ألفاء و عقوبات تبعية، و عقوبات تكميلية.

تعني العقوبات الأصلية الجز اء الأساسي للجريمة، و لا تقع إلا إذا نطق

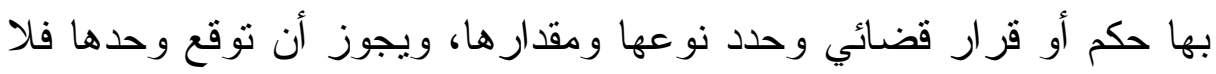
تكون إلى جانبها عقوبة تكميلية أو تبعية (؟).

وبالرجوع لنظام الغذاء يتضح أنه نص في مادته السادسة و الثلاثون المذكورة سلفاً على عقوبات أصلية وهي: الغرامة التي لا نزيد على ملئ مليون

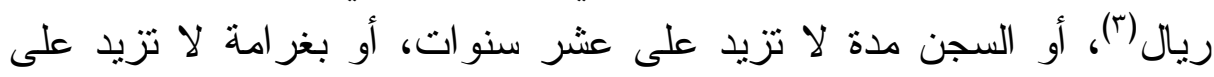

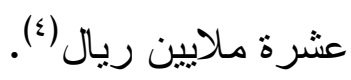

بينما تعني العقوبات التبعية ذلك الجزاء الثانوي الذي يلحق بالمحكوم

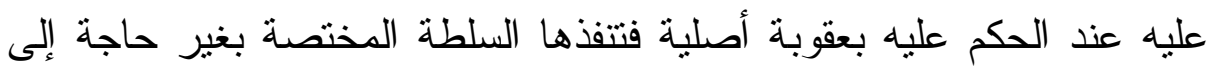

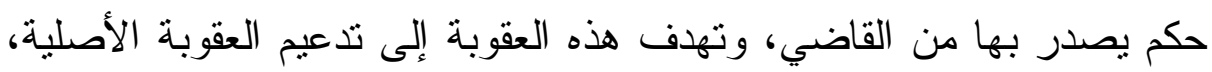

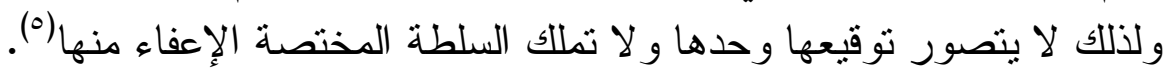

ومن قبيل ذللك نشر الحكم أو القرار المكتسب للقطعية على نفقة المخالف في ثناث صحف محلية، ير اعى في تحديدها مقر المنشأة الغذائية، ومكان وقوع المخالفة (؟).

( ) ) فقرة ج من المادة السادسة و الثناثثون من نظام الغذاء.

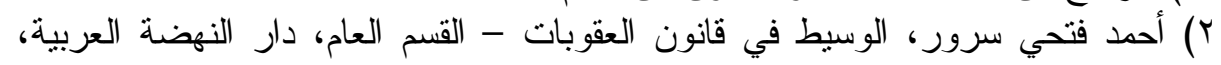

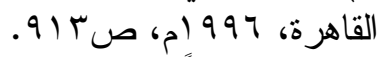

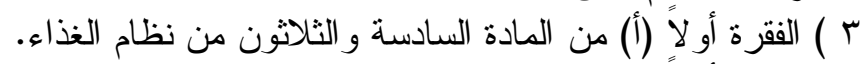

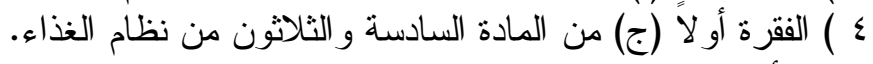

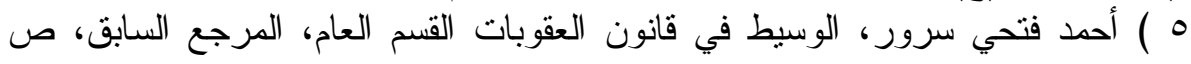

7 ) الفقرة رابعاً من المادة السادسة و الثظلاثون من نظام الغذاء. 
أما العقوبات التكميلية تهتم بالجز اء الثانوي الذي يوقع على المتهم عند

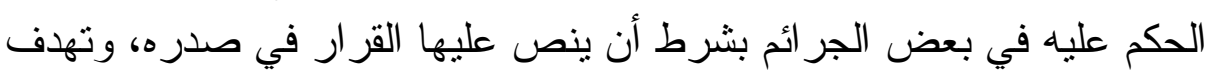

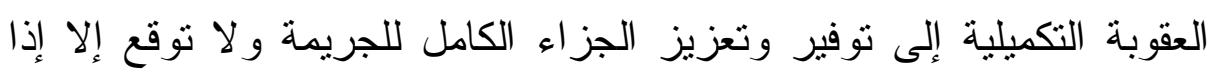

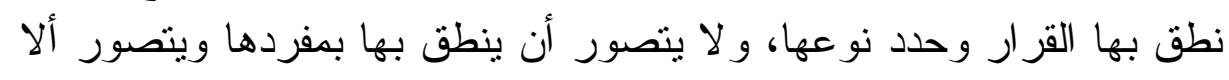

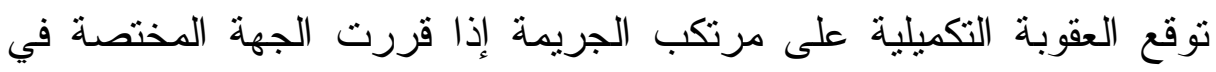

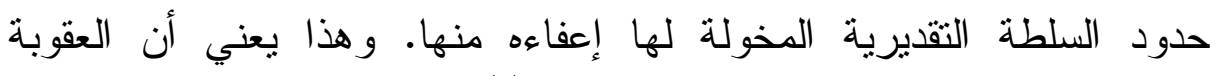
التكميلية قد تكون، وجوبية وقد تكون جو ازية (').

ومن قبيل ذلك منع المخالف من ممارسة أي عمل غذائي وذللك لمدة لا تتجاوز مائة وثمانين يوماً، أو تعليق الترخيص لمدة لا لا تتجاوز عاماً، أو إلغاء

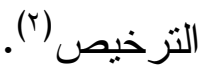

\section{ثانياً: تثديد العقاب وتكرار المخالفة:}

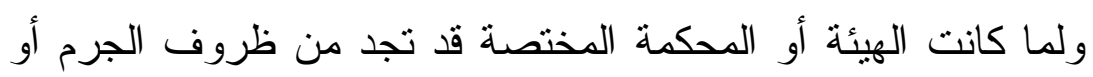

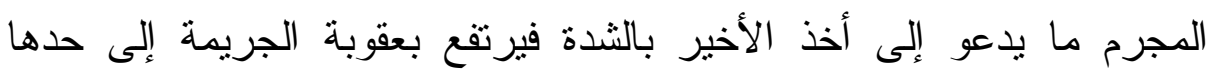

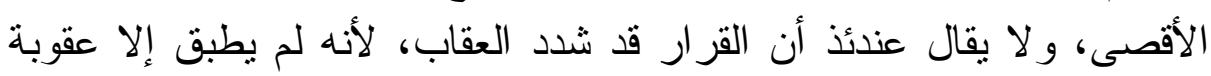

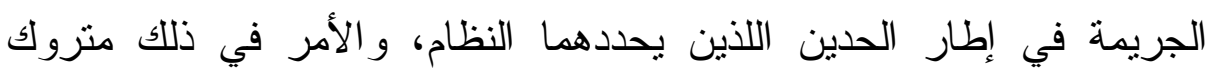
للسلطة التقديرية(r).

إلا أن النظام قد نص على تشديد الجريمة عن الحد الأقصى المقرر

لها في الأحوال العادية، وذلك بسبب تو افر ظروف تتصل بوقائع الدعوى أو

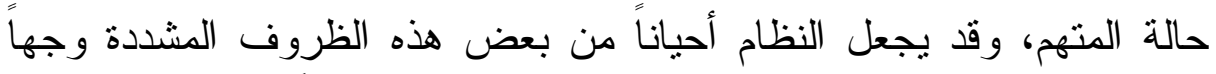

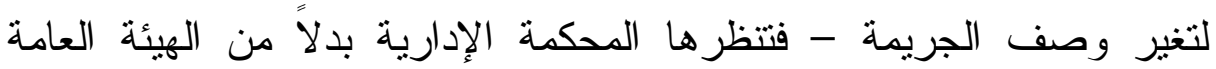

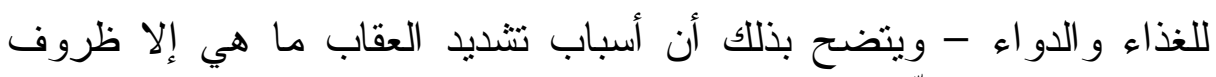
يجب فيها على مؤقّع العقاب أن يُعاقب المخالف بعقاب أنثد من العقاب المقرر

( ) هشام محمد فريد رسنت، شرح قانون العقوبات القسم العام، دار النهضة العربية،

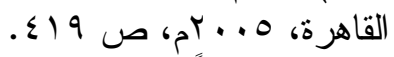

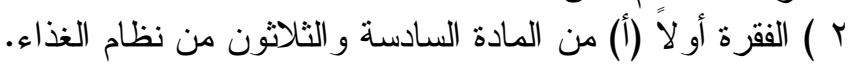

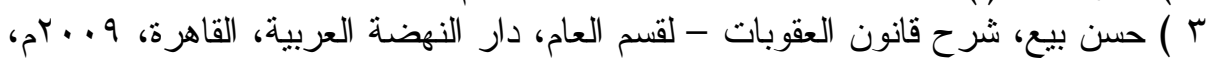
ص ص17 
أصلاً لجريمته، أي بعقاب أغلظ نوعاً أو يتجاوز مقداره الحد الأقصى المقرر

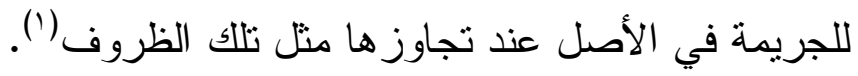

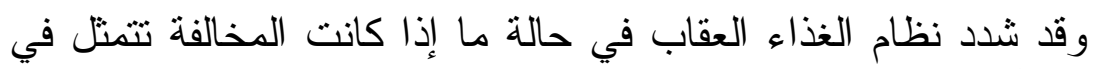

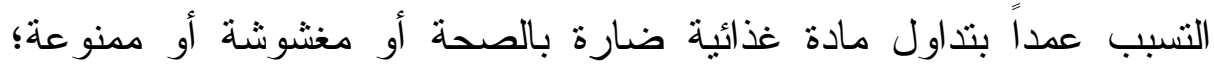

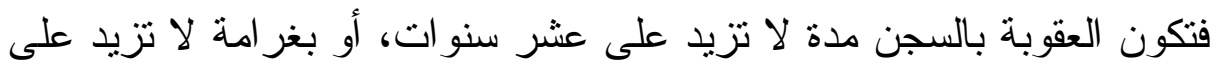

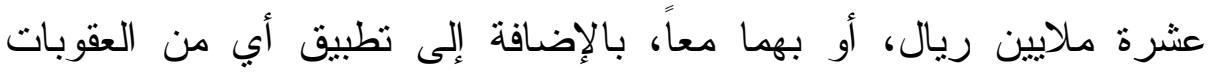

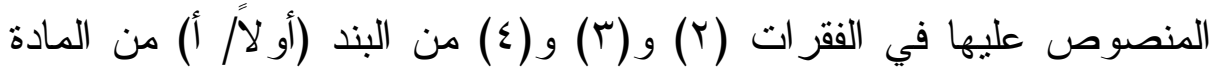
السادسة و الثنالثون. ونرى أن الذي دفع المنظم إلى هذه السياسة - العقابية - بالتشديد في

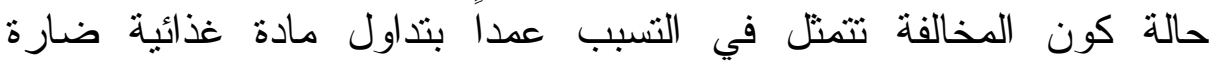

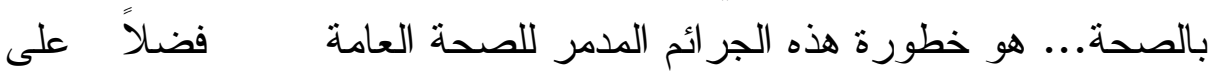
خطورتها على المستهلك. ويثور تساؤل في هذا الصدد وهو أثز تكرار ارتكاب المخالفة على ألى العقاب ؟ أجاز نظام الغذاء مضاعفة العقوبة في حال تكرار ارل ارتكاب

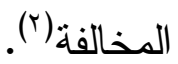

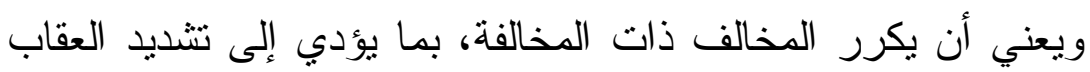
عليه، وذلك باعتبار أن المخالف الذي يكرر ارتكاب المخالفة، يفصح في حقيقة

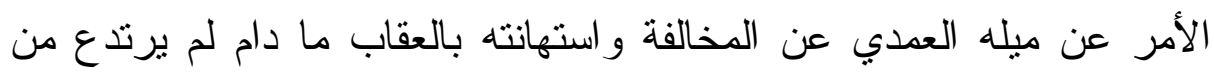

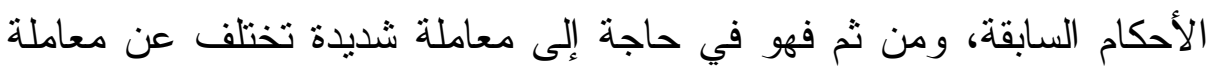

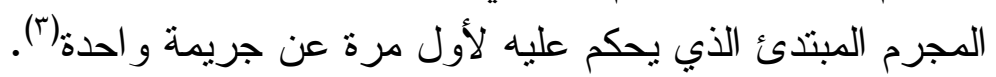

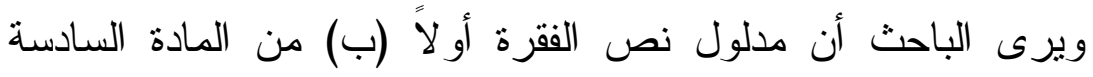

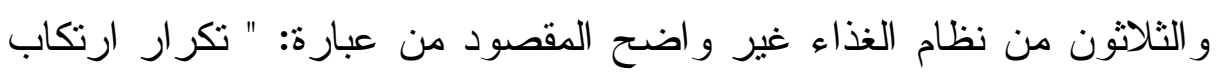
المخالفة " لذلك فهي تعني من وجهة نظرنا أمرين:

( ) أحمد فتحي سرور، الوسبط في قانون العقوبات القسم العام، المرجع السابق، صس • 1. r r الفقرة أو لاًا (ب) من المادة السادسة و الثلاثون من نظام الغذاء.

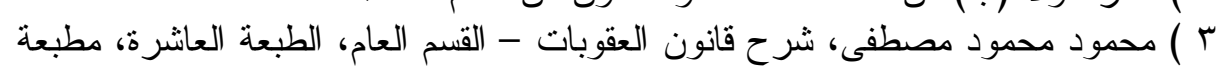

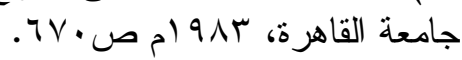


1. تكرار ارتكاب المخالفة أثناء عملية الضبط وهو ما يعني لاى شراح الأنظمة العقابية تعدد الدخالفات - بشأن عدد من السلع.

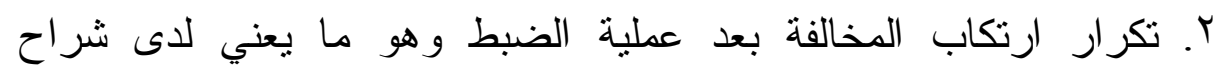
الأنظمة العقابية العود، أي العودة لارتكاب ذات العخاب العالفة مرة أخرة.

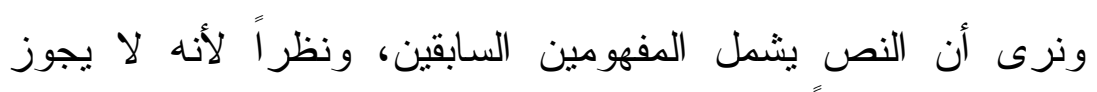

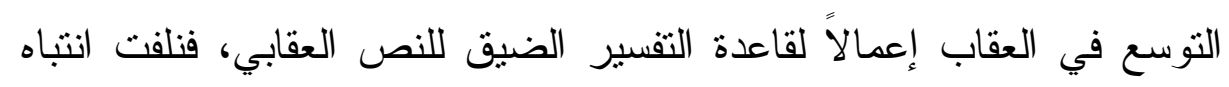

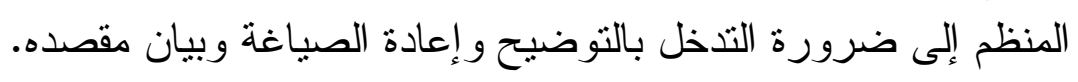

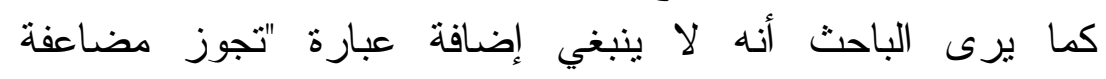

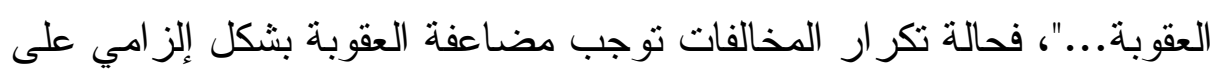

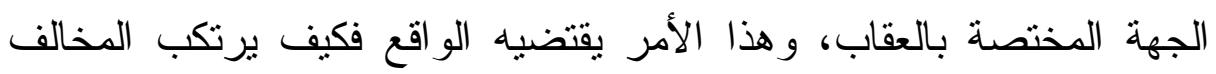

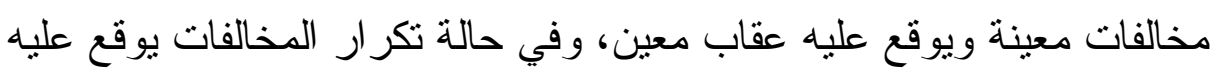

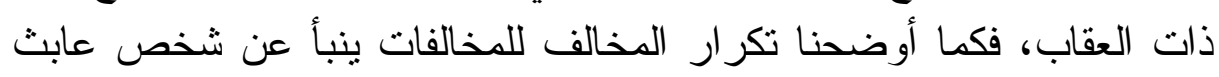

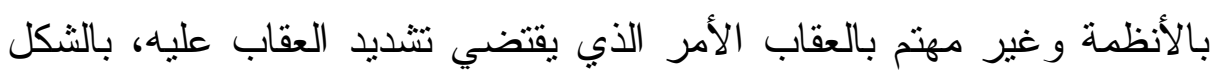

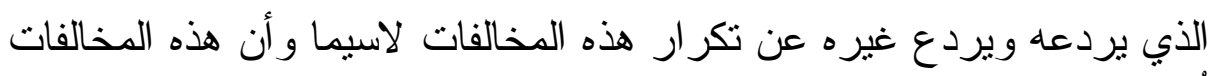

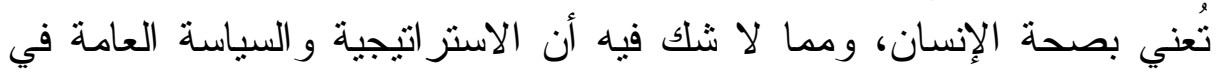
المملكة الحفاظ على صحة الإنسان. ثالثأ: الجهة المختصة بتوقيع العقاب: ينعقد الاختصاص في توقيع العقاب عن مخالفات نظام العام الغذاء للهيئة

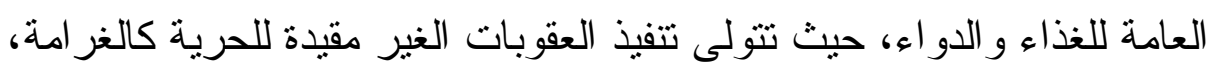

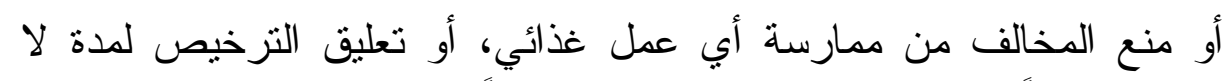

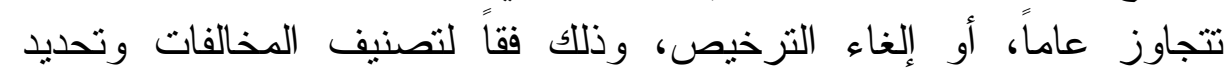

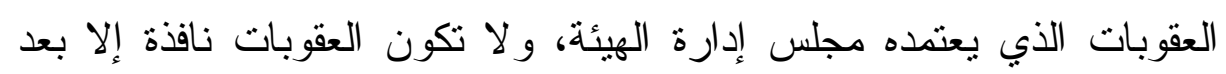

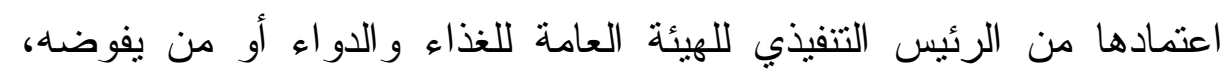

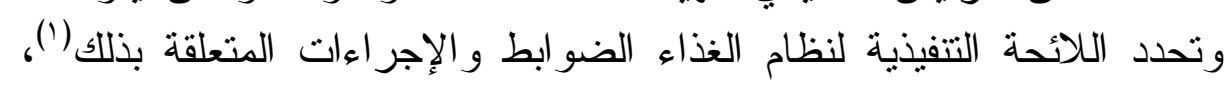

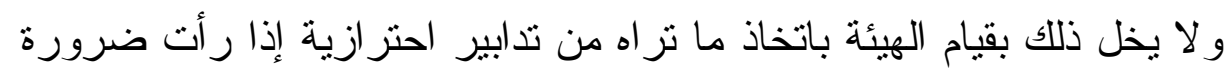

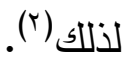

( ) في حدود علم الباحث لم تصدر حتى كتابة السطور اللائحة التتفيذية لهذا النظام. r ) ثانياً من المادة السادسة و الثنالثون من نظام الغذاء. 
ويرى الباحث أن نظام الغذاء منح سلطات و اسعة للهيئة العامة للغذاء

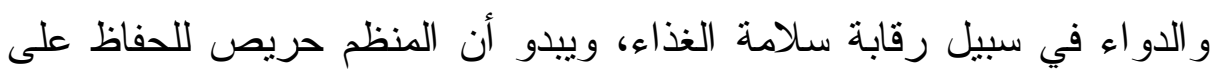

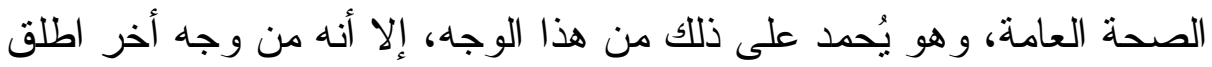

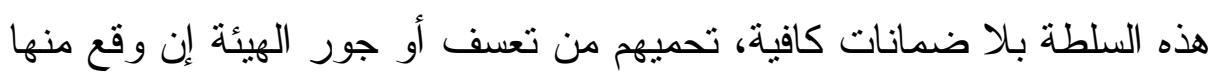
ذلك.

وفي هذا الصدد يثور تساؤل هام هو: مدى أحقية الموقع عليه

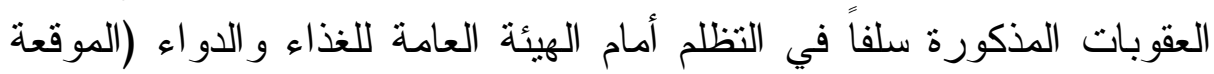

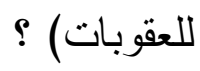

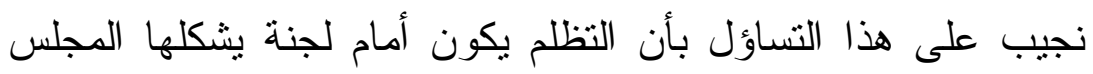

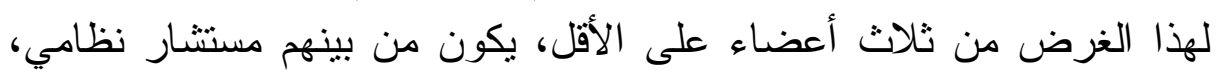
وتختص اللجنة بالنظر فيما يأتي ('):

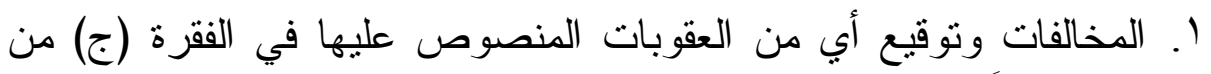

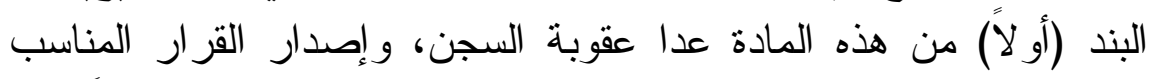

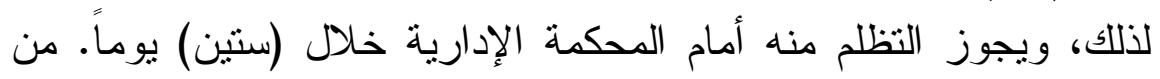
تاريخ إبلاغه به.

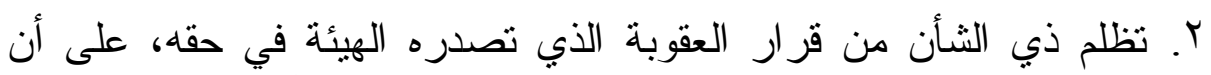
تبت اللجنة في التظلم خلال مدة لا تتجاوز (ستين) يوماً. وفي حالة انتهاء هذه المدة دون البت في التظلم، أو عدم قبول المخالف لقرار اللجنة؛ يجوز له التظلم من قر ار العقوبة أمام المحكمة الإدارية.

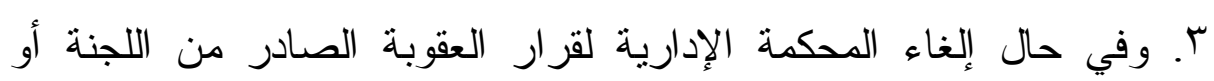

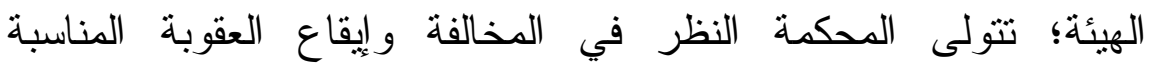
المنصوص عليها في هذه المادة.

بينما اسند الاختصاص في حالة توقع الحكم بعقوبة مقيدة للحرية

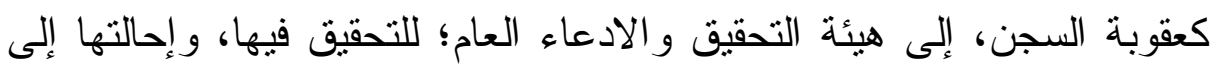

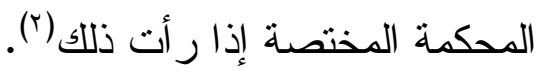

( ) الفقرة خامساً وسادساً من المادة السادسة و الثلاثون من نظام الغذاء.

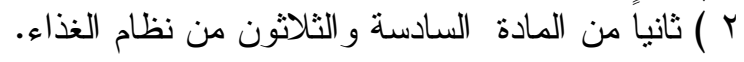


يرى الباحث أنه لا توجد آلية لإحالة القضايا التي يتوقع القضاء فيها

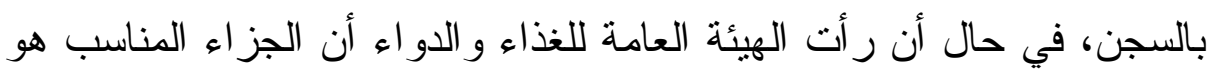

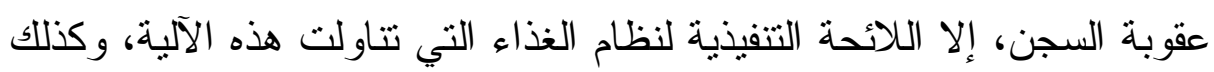

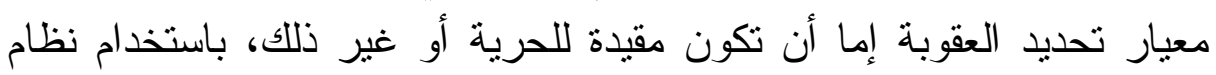

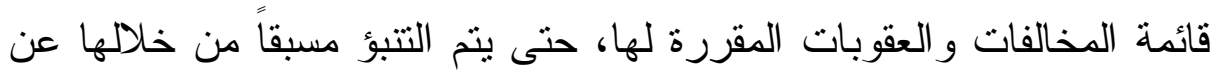

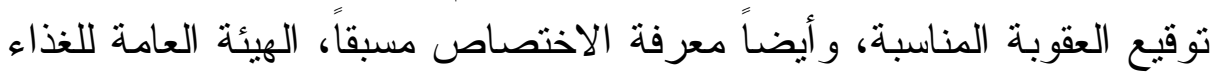
و الدو اء، أم المحكمة المختصة.

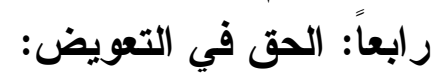

الثابت في الثريعة الإسلامية أن: "الضرر يز ال"، فهذه القاعدة مكونة

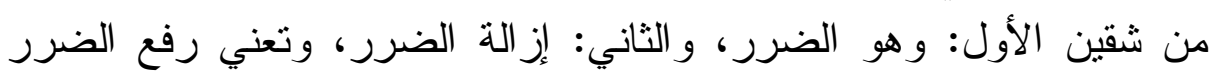
ونفيه بعد وقو عد ('). وبالرجوع للنظام يتضح أنه اتاح نظام الغذاء للمتضرر من أي مخالفة

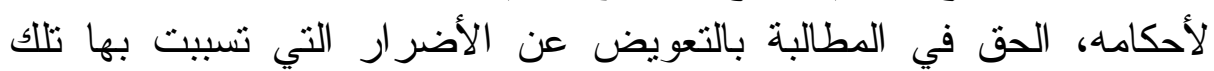

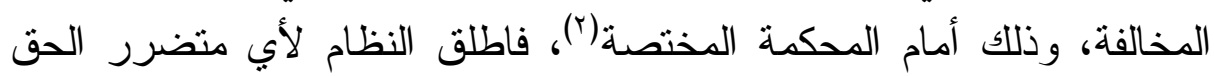
في المطالبة بالتعويض، شريطة أن يثبت ضرره وخطأ المخطئ و العلاقة

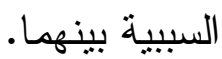

( ) مازن مصباح مصباح، قاعدة الضرر يز ال - حجيتها وضو ابطها، بحث محكم، منشور

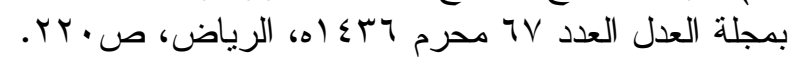
r r المادة السابعة و الثلاثون من نظام الغذاء. 


\section{الخاتمة}

تتاول الباحث السياسة القانونية لحماية سلامة الغذاء في المملكة العربية السعودية، وعرضه في ثلاثة مباحث، أوضح في المبحث الأول:

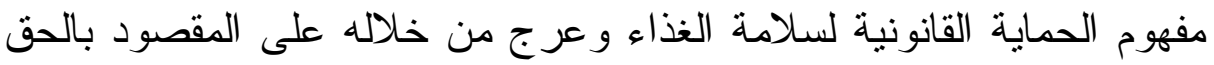

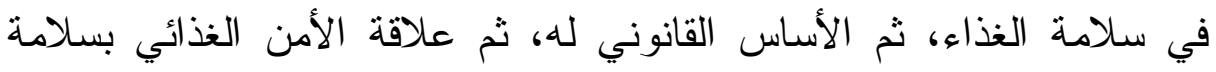

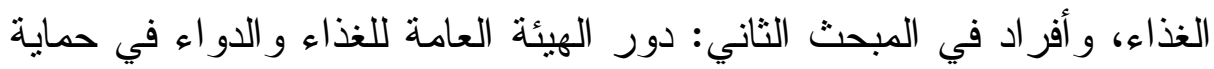

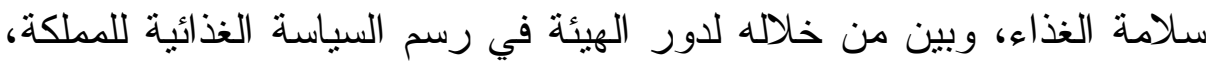

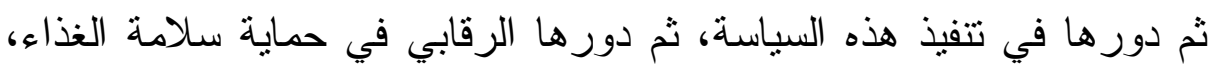
وتحدث في المبحث الثالث: عن استر اتيجية المملكة في تحقيق سلامة الغذاء دواء

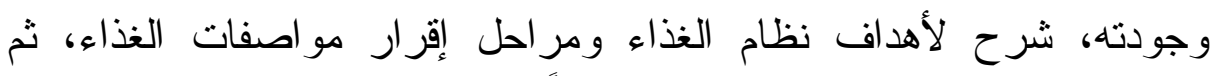

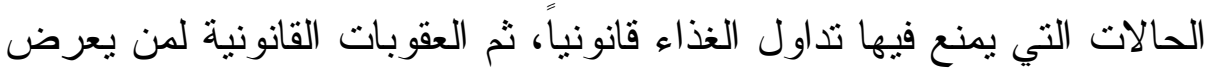
سلامة الغذاء للخطر ، ثم توصل الباحث إلى مجموعة من النتائج و التوصيات

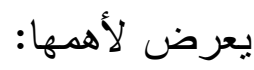

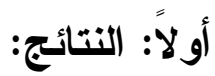

ا. يقع التزام المملكة بالحفاظ على سلامة الغذاء وعلى صحة المواطنين، تأسيساً على التزامها بتطبيق المبادئ المستمدة من الكتاب و السنة و التي

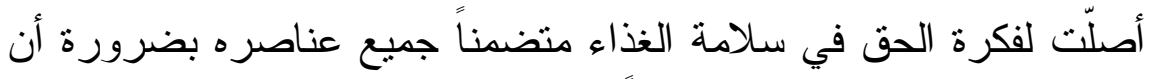
يكون كافي وصحي وطيب، فضلاً عن التز ام المملكة الأخلافي و الإنساني. r. تتحمل أي دولة تبعة المساءلة نتيجة التقاعس عن وضع أنظمة نستهدف تحسين وسلامة الغذاء وحمايته.

r. يتفق مفهوم الأمن الغذائي بسلامة الغذاء، من حيث إن كلاهما يهتم

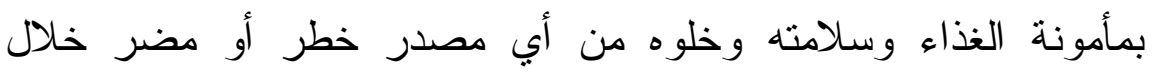

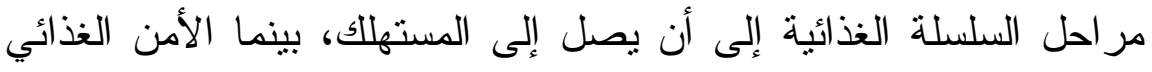

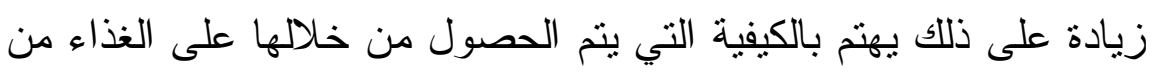
الداخل أو الخارج و الدخل المادي للأفر اد، وكفايته. 
ع. تتمحور السياسة الغذائية للمملكة في ثناثة محاور : ضمان سلامة الغذاء

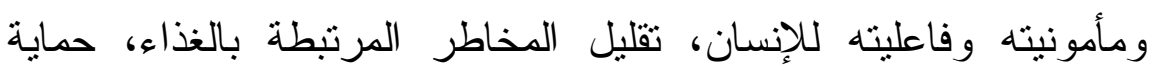

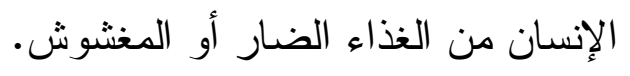

○. تبني الهيئة العامة للغذاء و الدواء معايير جودة وسلامة الغذاء، و استخدام

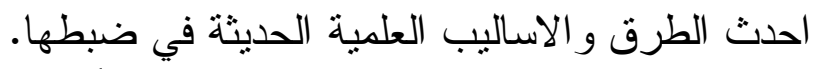

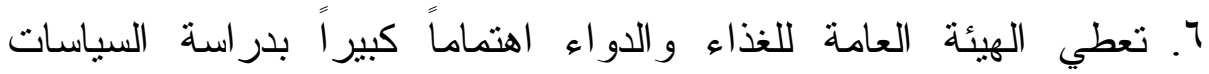

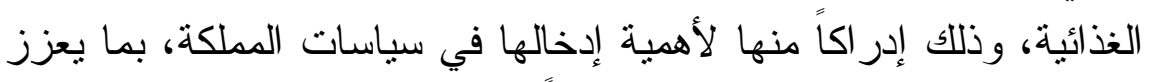

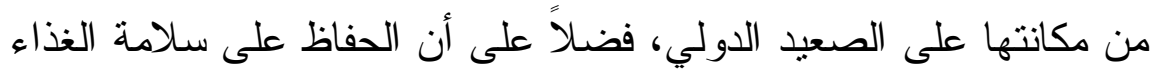
مطلب إسلامي. V. تدرك الهيئة العامة للغذاء و الدواء أهمية مستهلك المواد الغذائية ووعيه

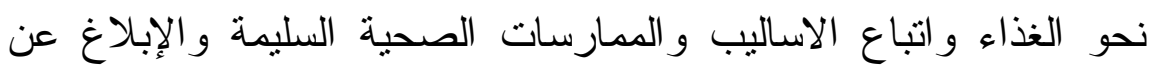
حالات الغش و التضليل و الفساد في المو اد الغذائية.

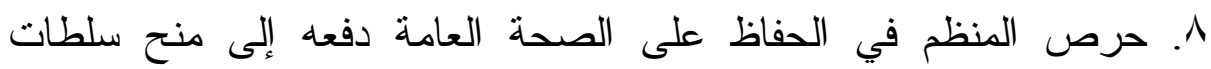
و اسعة للهيئة العامة للغذاء و الدو اء في سبيل رقابة سلامة الغذاء. ثانياً: التوصيات: 1. نناشد المنظم بضرورة تفعيل دور الهيئة وتمكينها من القيام بعملها على الثى الوجه المطلوب منها.

r. بذل المزيد من الجهود العلمية في البحث و الدراسة الميدانية لتتاول سلامة الأغذية باعنبار ها مصدر أساسي لصحة الإسئ في لإنسان.

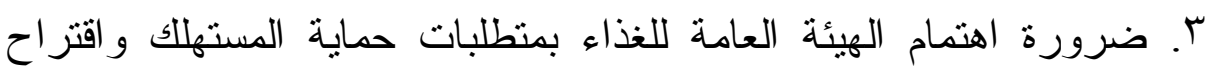
أنظمة حماية المستهلك من الأغذية غير المأمونة أو المنخفضة الجودة. ع. الاهتمام و المر اجعة الدورية للشروط الصحية والمواتية الصفات القية القياسية الخاصة بإنشاء المعامل و المصانع من قبل القطاع الخاص لتشمل عمليات التصنيع و التخزين و التجهيز و التوزيع للأغذية.

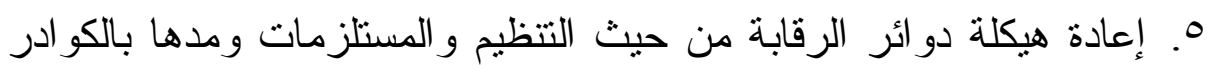

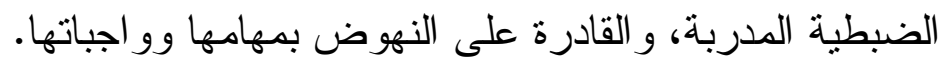


T. تفعيل الجانب الوقائي للهيئة، والعلاجية التي ترتبط بالمسببات الأساسية

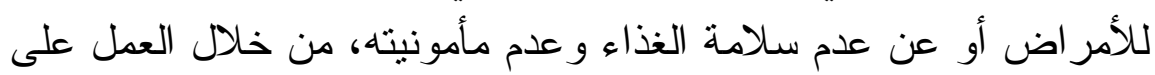
خلق بيئة نظيفة وصحية.

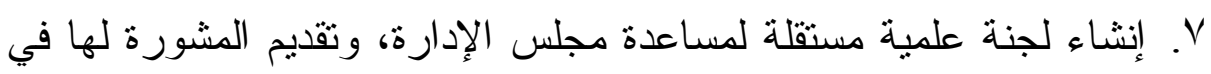

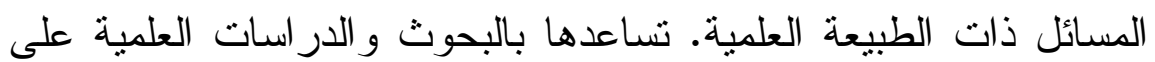
اتخاذ قرار ات رقابة الأغذية. ^. ضرورة إنثاء مختبرات و هيئات مستقلة عن الهيئة العامة للغذاء و الدواء ألغاء

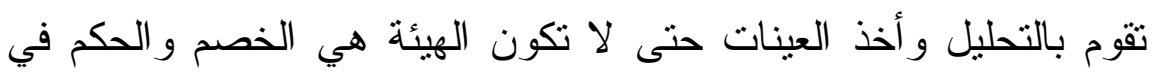

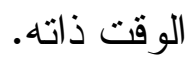

9-هجب أن يكون موظفي الهيئة العامة للغذاء و الدواء من الباحثين و العلماء

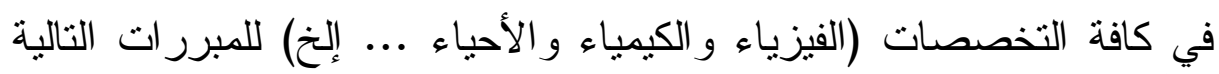

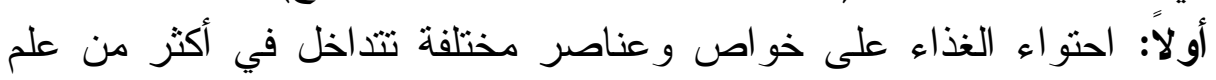

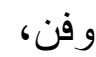
ثانياً: أن هذه الهيكلة الوظيفية تساعد على تفعيل الإجراءات الخاصة بحماية

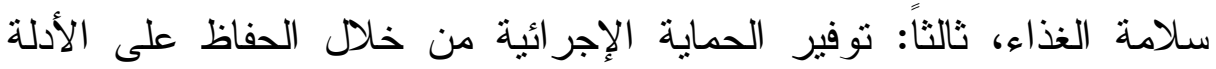

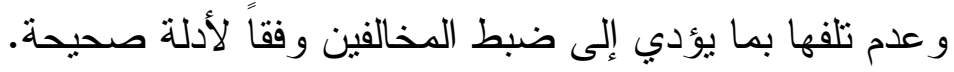

